\section{Pacific Northwest}

National Laboratory

Operated by Battelle for the

U.S. Department of Energy

\title{
Groundwater Monitoring Plan for the 216-B-63 Trench on the Hanford Site
}

\author{
M. D. Sweeney
}

November 2002

Prepared for the U.S. Department of Energy

under Contract DE-AC06-76RL01830 


\title{
DISCLAIMER
}

This report was prepared as an account of work sponsored by an agency of the United States Government. Neither the United States Government nor any agency thereof, nor Battelle Memorial Institute, nor any of their employees, makes any warranty, express or implied, or assumes any legal liability or responsibility for the accuracy, completeness, or usefulness of any information, apparatus, product, or process disclosed, or represents that its use would not infringe privately owned rights. Reference herein to any specific commercial product, process, or service by trade name, trademark, manufacturer, or otherwise does not necessarily constitute or imply its endorsement, recommendation, or favoring by the United States Government or any agency thereof, or Battelle Memorial Institute. The views and opinions of authors expressed herein do not necessarily state or reflect those of the United States Government or any agency thereof.

\author{
PACIFIC NORTHWEST NATIONAL LABORATORY \\ operated by \\ BATTELLE \\ for the \\ UNITED STATES DEPARTMENT OF ENERGY \\ under Contract DE-AC06-76RL01830
}

Printed in the United States of America
Available to DOE and DOE contractors from the Office of Scientific and Technical Information,
P.O. Box 62, Oak Ridge, TN 37831-0062;
ph: (865) 576-8401
fax: $(865) 576-5728$
email: reports@adonis.osti.gov

\begin{abstract}
Available to the public from the National Technical Information Service, U.S. Department of Commerce, 5285 Port Royal Rd., Springfield, VA 22161 ph: (800) 553-6847 fax: $(703) 605-6900$

email: orders@ntis.fedworld.gov

online ordering: http://www.ntis.gov/ordering.htm
\end{abstract}

This document was printed on recycled paper. 


\section{Groundwater Monitoring Plan for the 216-B-63 Trench on the Hanford Site}

M. D. Sweeney

November 2002

Prepared for

the U.S. Department of Energy

under Contract DE-AC06-76RL01830

Pacific Northwest National Laboratory

Richland, Washington 99352 


\section{Summary}

This document presents a groundwater monitoring plan, under Resource Conservation and Recovery Act of 1976 (RCRA) regulatory requirements found in Washington Administrative Code 173-303-400 and, by reference, requirements in 40 CFR 265.93(d)(6) for the 216-B-63 trench (B-63 trench) in the 200 East Area of the Hanford Site. The objective of RCRA monitoring is to determine whether any hazardous constituents are detectable in the groundwater beneath the trench.

The groundwater monitoring network described in this plan includes twelve RCRA-compliant wells to monitor the aquifer in the immediate vicinity of the B-63 trench. No exceedances of RCRA-regulated materials have yet been reported in groundwater passing beneath the B-63 trench.

This site will be sampled semiannually for indicator parameters including $\mathrm{pH}$, specific conductance, total organic carbon, and total organic halides. Site-specific parameters include ICP metals. These constituents, as well as anions, alkalinity, and turbidity, will be sampled annually. Groundwater elevations will be recorded semiannually.

This monitoring plan will serve as the basis for demonstrating compliance with RCRA monitoring requirements at the B-63 trench. 


\section{Contents}

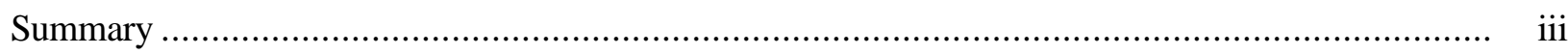

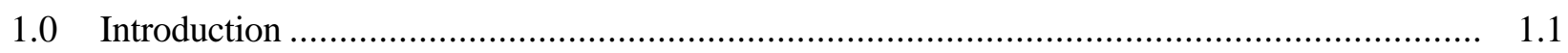

2.0 Description of the 216-B-63 Trench......................................................................... 2.1

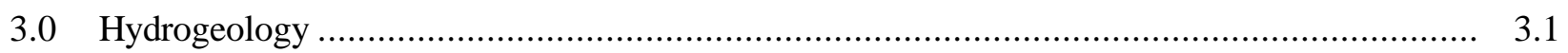

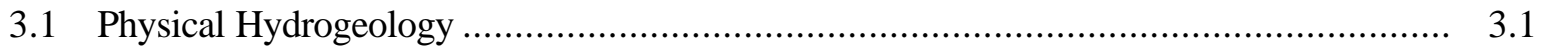

3.2 Summary of Groundwater Monitoring Results........................................................... 3.1

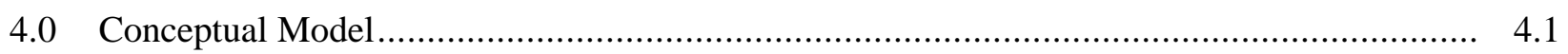

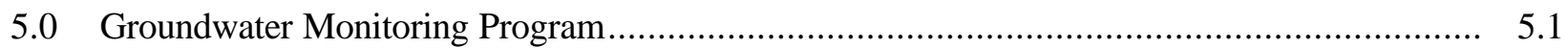

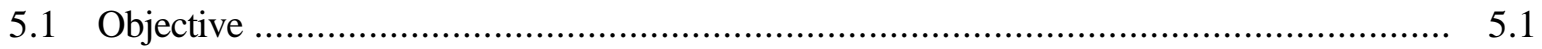

5.2 Sampling and Analysis Plan ......................................................................... 5.1

5.2.1 Monitoring Well Network......................................................................... 5.1

5.2.2 Constituent List and Sampling Frequency ……………………………….... 5.2

5.2.3 Network Evaluation ............................................................................ 5.2

5.2.4 Sampling and Analysis Protocol................................................................ 5.4

5.2.5 Quality Assurance and Quality Control........................................................ 5.5

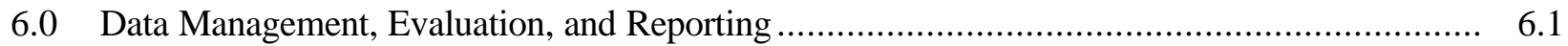

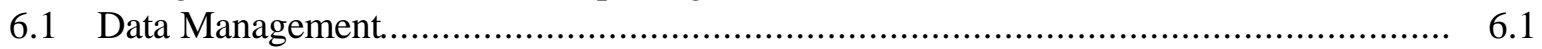

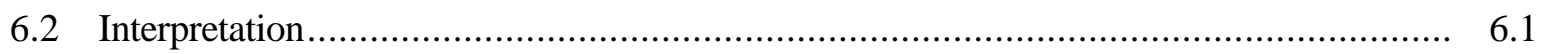

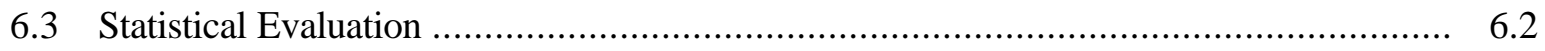

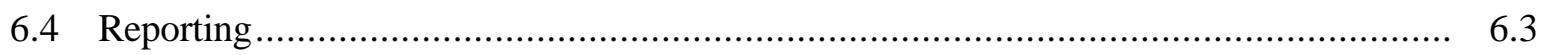

7.0 Outline for Assessment Monitoring Plan ............................................................................. 7.1

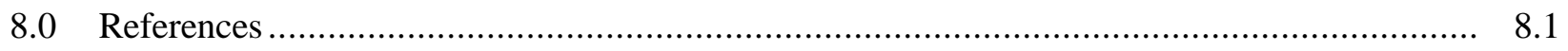

Appendix - As-Built Drawings for the 216-B-63 Trench Network Wells....................................... A.1 


\section{Figures}

3.1 Water-Level Elevation in RCRA-Compliant Monitoring Wells, March 2002 ..................... 3.2

5.1 Current Network of Groundwater Monitoring Wells for the B-63 Trench........................ 5.3

5.2 Typical Construction, RCRA-Compliant Monitoring Well .......................................... 5.4

7.1 Outline for Groundwater Quality Assessment Monitoring Plan ...................................... 7.2

\section{Tables}

3.1 Monitoring Wells and Constituents for the 216-B-63 Trench.......................................... 3.3

3.2 Critical Means for the 216-B-63 Trench for Fiscal Year 2002 Comparisons ......................... 3.4

5.1 Locations, Depths, and Screened Intervals for Groundwater Monitoring Wells Around the 216-B-63 Trench ...................................................................................................

6.1 Reports Required for Compliance with 40 CFR 265, Subpart F, for Groundwater Monitoring .. 6.4 


\subsection{Introduction}

This document presents a revision to the groundwater monitoring plan (Sweeney 1995) for the 216-B-63 trench (B-63 trench). The groundwater monitoring plan is based on requirements for interimstatus facilities, as defined by the Resource Conservation and Recovery Act of 1976 (RCRA) and amended by the Hazardous and Solid Waste Amendments of 1984. These regulations are promulgated by the Washington State Department of Ecology (Ecology) in Washington Administrative Code (WAC) 173-303-400 and, by reference, the Code of Federal Regulations, 40 CFR 265, Subpart F.

Groundwater monitoring began at the B-63 trench in 1988. Under the definitions for RCRA interim status, the B-63 trench required a detection-level groundwater monitoring program because it received wastewater from B Plant. In the past, this wastewater contained hazardous waste and materials. Discharges to the B-63 trench were discontinued in 1992.

The purpose of this plan is to present an indicator evaluation groundwater monitoring program that will detect adverse impacts of the B-63 trench on the quality of groundwater in the uppermost aquifer beneath the trench (40 CFR 265.93[d]). This plan describes the methods that will be used to determine whether any hazardous constituents are detectable in the groundwater beneath the trench.

Upgradient wells and downgradient wells will be monitored semiannually for indicator parameters and annually for the constituents described in Chapter 3. This document contains the same well list and statistical methods as those in Sweeney (1995) but includes additional and revised details about sampling and analysis, data management, and statistics.

The B-63 trench is within the 200-BP-5 Groundwater Operable Unit and the 200-CS-1 Source Operable Unit. A closure plan for each of these units will be submitted to Ecology. Final disposition of the B-63 trench will be outlined in the post-closure agreement negotiated between the U.S. Department of Energy (DOE) and Ecology. 


\subsection{Description of the 216-B-63 Trench}

The information in this section was adapted from the 200-CS-1 Operable Unit RI/FS Work Plan and RCRA TSD Unit Sampling Plan (Richland Operations Office 2000).

The B-63 trench was an open, unlined, man-made depression that was terminated approximately $427 \mathrm{~m}$ $(1400 \mathrm{ft})$ from its head end. The trench boundary is located at the southwest perimeter of the 218-E-12B Burial Ground (Low-Level Burial Ground 2) in the 200 East Area. The trench was approximately $1.2 \mathrm{~m}(4 \mathrm{ft})$ wide and had an average depth of $3 \mathrm{~m}(10 \mathrm{ft})$. The head end was constructed using

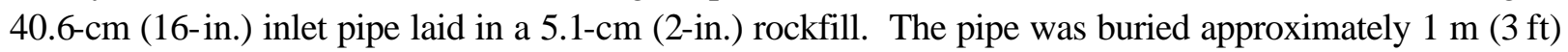
below grade and the rockfill extended $3.1 \mathrm{~m}(10 \mathrm{ft})$ from the head wall.

The B-63 trench was constructed prior to 1970 as a percolation trench to receive emergency cooling water and chemical sewer wastes from B Plant. According to the Waste Information Data System, the B-63 trench received effluent from 221-B (B Plant), 225-B (Waste Encapsulation and Storage Facility), and 271-B (B Plant Office and Service Building). Unlike the other B-series trenches (e.g., 216-B-2-1 trench), the B-63 trench was not connected to the 216-B-3 Pond (B Pond) system. It was designed to receive diverted contaminated cooling water and prevent it from reaching the $\mathrm{B}$ Pond.

Operations at the B-63 trench began on March 22, 1970, after an unplanned release to 216-B-2-2

(UPER-200-E-138). Source contributors to the B-63 trench included floor, funnel, and sink drains; steam condensate and/or cooling water; tank overflow and drain effluent; swamp effluent; and rain water. The B-63 trench received cooling water from both B Plant and In-tank Solidification Unit Number 2 from March 1970 to May 1970 (Jacobs and Uebelacker 1971). From May 1970 until February 1992, the trench also began receiving B Plant chemical sewer effluent. In February 1992, the B Plant chemical sewer effluent was combined with the B Plant cooling water effluent and discharged into the 216-B-3 Pond. The trench was removed from service in 1992.

Interim stabilization measures were completed at the B-63 trench in November 1994. The site was backfilled with clean fill and downposted in status from Surface Contamination Area (SCA) to Underground Radioactive Material (URM) in November 1994. The site was permanently isolated by filling the weir box at the head end of the ditch with concrete on December 12, 1994. Prior to its stabilization, the ditch had an earth shielding berm and a side slope of approximately 10:6. 


\subsection{Hydrogeology}

The geology and hydrology of the B-63 trench are described in detail in Sweeney (1995) and in compilation reports on the 200 East Area (e.g., Lindsey et al. 1992; Williams et al. 2000). The following summary is taken from those documents.

\subsection{Physical Hydrogeology}

The uppermost aquifer beneath the B-63 trench is unconfined and occurs within the undifferentiated Hanford formation. According to geologic records and as-built diagrams, existing shallow wells in the B-63 trench monitoring network are completed within a sandy to gravelly sand unit. The water table elevation near and beneath the B-63 trench is approximately $122 \mathrm{~m}$ above mean sea level $(\sim 75 \mathrm{~m}$ below ground surface). The base of the unconfined aquifer, which under the B-63 trench is the top of the Elephant Mountain Member basalt, is approximately $115 \mathrm{~m}$ above mean sea level ( $\sim 0 \mathrm{~m}$ below ground surface).

Groundwater hydraulic gradients in the vicinity of the B-63 trench were for decades highly influenced by the hydraulic mound that had developed under B Pond, a facility that entered service in 1945. Decommissioning of B Pond has resulted in a dramatic decline in groundwater elevations throughout the 200 East Area. This decline has produced a region of groundwater gradients measured in centimeters across the length of the 200 East Area, a distance of more than $4 \mathrm{~km}$. The lack of appreciable gradient in 200 East results in high uncertainty in the groundwater flow rate and direction. The groundwater flow direction beneath the B-63 trench in particular is generally to the west-southwest (Spane 1999). Figure 3.1 illustrates the water-level elevation in March 2002 from wells in the vicinity of the B-63 trench. The saturated thickness of the unconfined aquifer beneath the B-63 trench is approximately $7 \mathrm{~m}$. The thickness of exposed saturated sediments to the screened interval of the B-63 trench wells ranges from approximately $1.4 \mathrm{~m}$ in well 299-E27-17 to $4.6 \mathrm{~m}$ in well 299-E27-18.

An estimate of the average linear groundwater velocity near the B-63 trench can be calculated, assuming horizontal flow and a homogeneous aquifer, using Darcy's Law. The calculated velocity ranges from approximately 0.01 to $0.1 \mathrm{~m} / \mathrm{d}$ (Hartman 2000, Table A.2).

\subsection{Summary of Groundwater Monitoring Results}

Groundwater beneath the B-63 trench has been monitored by a RCRA-compliant monitoring network since 1988. The original detection-level monitoring network (circa 1987) consisted of five monitoring wells; none of the original wells is part of the current network. An aggressive schedule of RCRA well installation between 1987 and 1992 resulted in the twelve monitoring wells that now constitute the B-63 trench network. Five upgradient and seven downgradient wells surround the entire length of the trench. Portions of the monitoring network are used for other RCRA facilities as well, including the LowLevel Waste Management Area 2 and the single-shell tank waste management area B-BX-BY. 


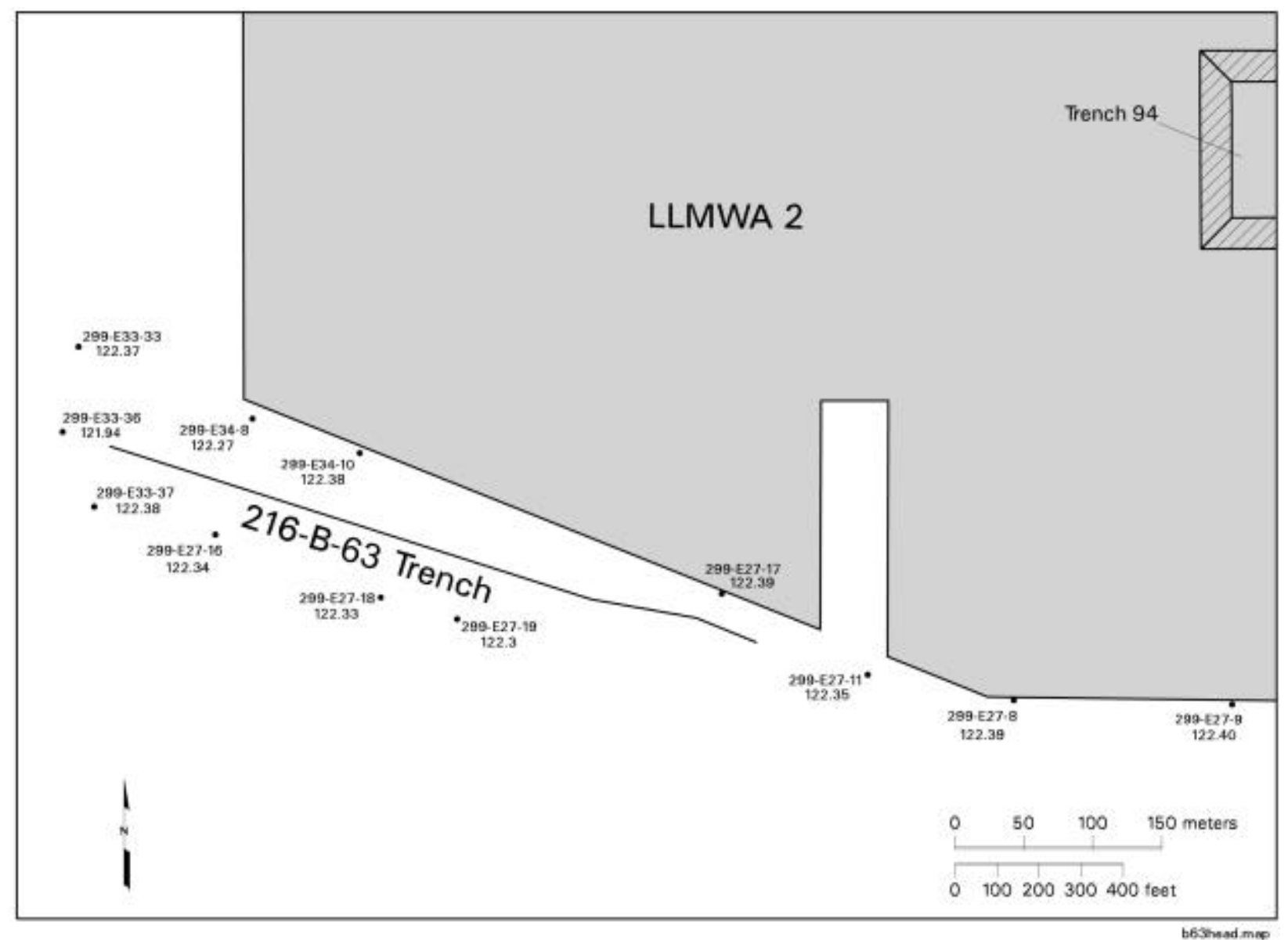

Figure 3.1. Water-Level Elevation in RCRA-Compliant Monitoring Wells, March 2002

The chemical composition of groundwater in the unconfined system beneath the B-63 trench includes calcium-bicarbonate, sodium-bicarbonate, and calcium-sulfate types (Graham et al. 1981). Calcium bicarbonate is the most prevalent in the groundwater. However, there is considerable variability in chemical composition of the groundwater beneath the 200 Areas. Prominent man-made contributors to impacts on groundwater include tritium, nitrate, calcium, and sulfate.

Groundwater monitoring continues to provide evidence that dangerous constituents from the B-63 trench have not entered groundwater. The RCRA interim-status indicator parameters are $\mathrm{pH}$, specific conductance, total organic carbon, and total organic halides (40 CFR 265.92 [b][3]). Included in the analysis list (Table 3.1) for this trench are alkalinity and turbidity. Alkalinity is used with metals and anions to calculate charge balance (a check on analytical accuracy), and turbidity is used to evaluate metals analysis results. Statistical analyses revealed no exceedances in $\mathrm{pH}$, specific conductance, total organic carbon, or total organic halides (Table 3.2). Revised comparison values of these analyses, if needed, are published annually in the Hanford Site annual groundwater report (e.g., Hartman 2000). 
Table 3.1. Monitoring Wells and Constituents for the 216-B-63 Trench

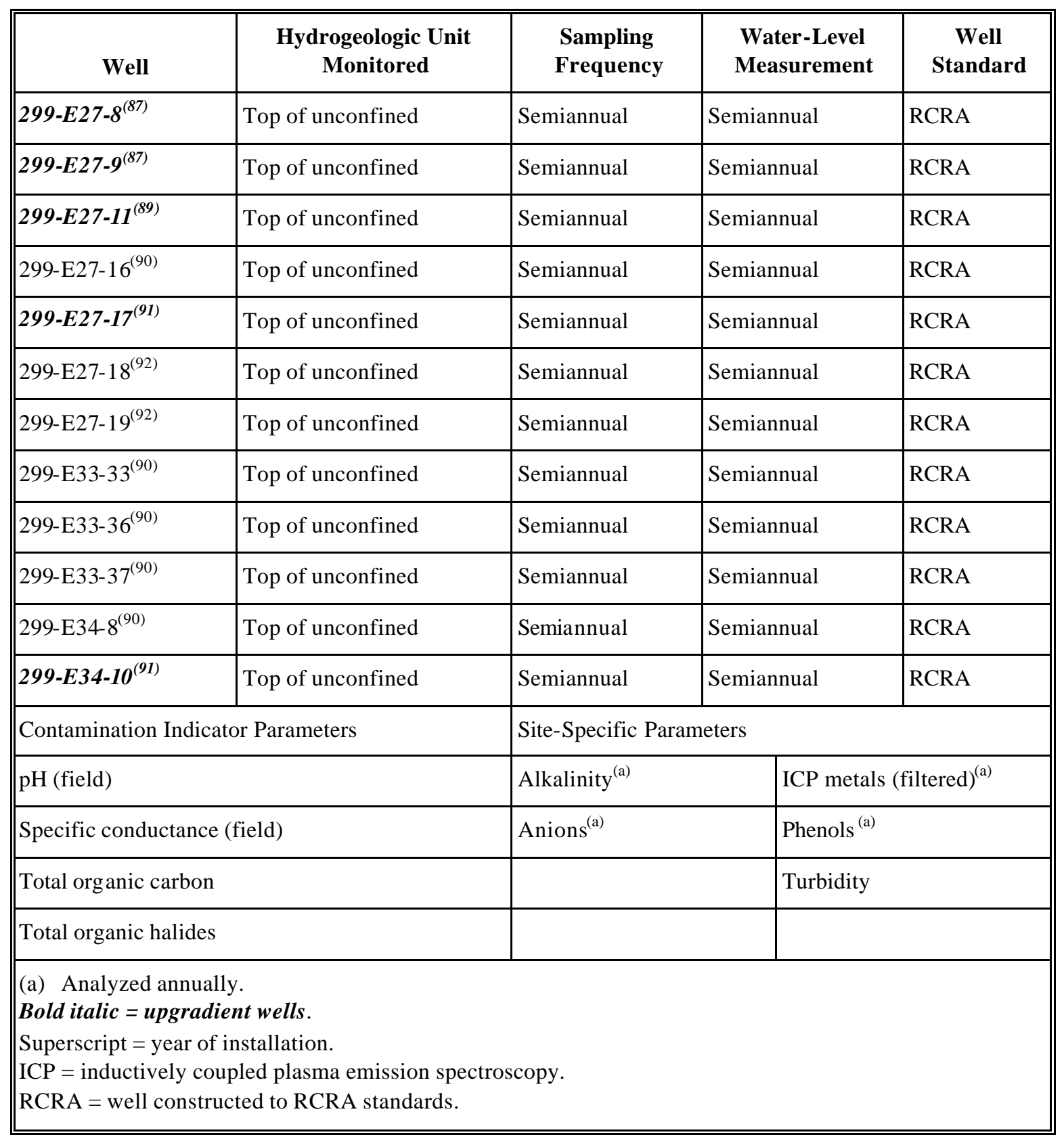


Table 3.2. Critical Means for the 216-B-63 Trench for Fiscal Year 2002 Comparisons $^{(a)}$

\begin{tabular}{|c|c|c|c|c|c|c|c|}
\hline Constituent, unit & $\mathbf{n}$ & df & $\mathbf{t}_{c}$ & $\begin{array}{c}\text { Average } \\
\text { Background }\end{array}$ & $\begin{array}{l}\text { Standard } \\
\text { Deviation }\end{array}$ & Critical Mean & $\begin{array}{l}\text { Upgradient/ } \\
\text { Downgradient } \\
\text { Comparison Value }\end{array}$ \\
\hline $\begin{array}{l}\text { Specific conductance, } \\
\mu \mathrm{S} / \mathrm{cm}\end{array}$ & 20 & 19 & 4.267 & 404.384 & 23.862 & 508.7 & 508.7 \\
\hline Field pH & 20 & 19 & 4.572 & 8.053 & 0.079 & {$[7.68,8.42]$} & {$[7.68,8.42]$} \\
\hline $\begin{array}{l}\text { Total organic carbon, }{ }^{(c)} \\
\mu \mathrm{g} / \mathrm{L}\end{array}$ & $20^{(\mathrm{b})}$ & 19 & 4.267 & 523.75 & 242.809 & $1,585.5$ & $1,585.5$ \\
\hline $\begin{array}{l}\text { Total organic halides, }{ }^{(\mathrm{c}, \mathrm{d})} \\
\mu \mathrm{g} / \mathrm{L}\end{array}$ & 20 & 19 & 4.267 & 2.589 & 1.082 & 7.3 & 15.1 \\
\hline \multicolumn{8}{|c|}{$\begin{array}{l}\text { (a) Based on semiannual sampling events from April } 2000 \text { to October } 2001 \text { for field parameters and from January } 2000 \text { to } \\
\text { April } 2001 \text { for total organic carbon and total organic halides for upgradient wells 299-E27-8, 299-E27-9, 299-E27-11, } \\
\text { 299-E27-17, and 299-E34-10. }\end{array}$} \\
\hline \multicolumn{8}{|c|}{$\begin{array}{l}\text { (b) Excluded one unrepresentative measurement of } 11,000 \mu \mathrm{g} / \mathrm{L} \text { collected on October } 20,2000 \text {, from well 299-E27-9. } \\
\text { (c) Critical mean calculated from values reported below vendor's specified method detection limit. } \\
\text { (d) Upgradient/downgradient comparison value is the most recent determined limit of quantitation (see Hartman 2000, } \\
\text { Table B.22). } \\
\text { df = Degrees of freedom ( } \mathrm{n}-1 \text { ). } \\
\mathrm{n}=\text { Number of background replicate averages. } \\
\mathrm{t}_{c}=\text { Bonferroni critical t-value for appropriate df and } 48 \text { comparisons. }\end{array}$} \\
\hline
\end{tabular}




\subsection{Conceptual Model}

The B-63 trench received several waste streams emanating from B Plant during its operations. The open and unlined trench allowed liquid effluents to evaporate and percolate into the vadose sediments along its entire length. Groundwater monitoring results to date have not shown increases in regulated dangerouswaste constituents attributed to discharges to the B-63 trench. Should contamination eventually be detected, however, it most likely would be found at the head end of the trench where most of the infiltration occurred. Direct evidence for this type of nonuniform breakthrough to groundwater from a line source has been observed at the 216-A-29 ditch, in which sulfate concentrations were observed first in head-end monitoring wells.

The potential for migration of residual contamination from the vadose zone to groundwater is lessened by the cessation of liquid effluent discharges to the B-63 trench. Infiltration of precipitation is the only potential force capable of moving a significant portion of the remaining contaminants to groundwater. The current mean annual precipitation is $16 \mathrm{~cm}$, with most of the annual accumulation occurring between November and February (Fayer and Walters 1995). Recharge in the B-63 trench area is estimated to be between 10 and $20 \mathrm{~mm}$ annually. The range of recharge rates depends on a variety of factors. No recent infiltration abatement measures have been implemented at the B-63 trench. The risk of infiltration by snow melt and the potential for vertical migration of contaminants, however, still is considered low because of low precipitation. The rate of movement for moisture through the vadose has been estimated to be as high as $2 \mathrm{~m}$ per year (Glendon Gee, personal communication).

Groundwater flow beneath the B-63 trench resides in an unconfined system within the Hanford formation. The site-specific hydraulic conductivity reported in Sweeney (1995) ranges from 51.9 to $198.3 \mathrm{~m} / \mathrm{d}$. Hydraulic conductivity also is assumed to be high regionally due to the lack of appreciable gradient across large portions of the 200 East Area. This low-gradient field leads to low flow velocities, generally on the order of millimeters to centimeters per day in a direction moving west-southwest (Hartman 2000, Table A.2). Because of the difficulty in assessing the hydraulic gradient in the 200 East Area, the flow velocity and direction are complicated and subject to wide variability. 


\subsection{Groundwater Monitoring Program}

This chapter presents the objective and details of the sampling and analysis plan associated with the groundwater monitoring program for the B-63 trench.

\subsection{Objective}

The objective of this monitoring program is to determine whether discharges to the trench have contaminated the groundwater beneath the B-63 trench with RCRA-regulated constituents.

\subsection{Sampling and Analysis Plan}

The upgradient and downgradient monitoring wells for the detection network are described in this section. Additional information is provided on the types of hydrogeologic data collected for the network, the sampling frequency, and groundwater constituents that will be analyzed.

\subsubsection{Monitoring Well Network}

The construction details and lithologic information for the B-63 trench network wells are given as as-built diagrams in the Appendix. The coordinates, total depth, and screened intervals are summarized in Table 5.1.

The indicator evaluation groundwater monitoring program consists of the B-63 trench monitoring network as described in Table 5.1 and shown in Figure 5.1. The network viability has been tested using the Monitoring Efficiency Model (MEMO) (Wilson et al. 1992), based on current groundwater flow conditions. The MEMO was run using the B-63 trench groundwater monitoring network wells, and a general groundwater flow direction to the southwest of the B-63 trench has been calculated. The monitoring efficiency is $68.5 \%$. Most of the unmonitored portion is at the tail end of the ditch, which is less likely to impact groundwater.

The twelve groundwater monitoring wells that currently cover the B-63 trench are located around the site as shown in Figure 5.1. All twelve wells were installed to RCRA standards for well construction (WAC 173-160) (Figure 5.2).

Wells 299-E27-9, -8, -11, and -17 provide upgradient coverage for the tail end of the B-63 trench. Upgradient coverage of the head end is provided by well 299-E34-10. Downgradient wells are concentrated around the head end of the ditch. The separation between upgradient and downgradient wells on the tail end is approximately $200 \mathrm{~m}$. This is the distance between upgradient well 299-E27-17 and downgradient well 299-E27-19.

Replacement wells for the current network may be considered because of declining water levels, changing flow directions, and programmatic considerations. These wells will be located according to the current understanding of hydrogeologic conditions under the facility, projected water-level elevations and flow 
Table 5.1. Locations, Depths, and Screened Intervals for Groundwater Monitoring Wells Around the 216-B-63 trench

\begin{tabular}{||l|c|c|c|c|c||}
\hline \multirow{2}{*}{ Well Number } & \multicolumn{2}{|c|}{ Coordinates (m) } & Depth to Bottom & $\begin{array}{c}\text { Water } \\
\text { Remaining in Screen (m) } \\
\text { Casing (m) }\end{array}$ & $\begin{array}{c}\text { Screen Length } \\
\text { (m) }\end{array}$ \\
\cline { 2 - 6 } & Easting & Northing & 119.6 & 2.9 & 6.1 \\
\hline 299-E27-8 & 574759.37500 & 137044.53100 & 118.4 & 4.1 & 5.9 \\
\hline 299-E27-9 & 574917.87500 & 137041.31200 & 118.6 & 3.8 & 6.4 \\
\hline 299-E27-11 & 574653.18800 & 137063.00000 & 118.8 & 3.6 & 6.4 \\
\hline 299-E27-17 & 574547.31200 & 137122.01600 & 118.2 & 1.6 & 6.4 \\
\hline 299-E27-18 & 574299.62500 & 137119.29700 & 117.6 & 4.8 & 6.1 \\
\hline 299-E27-19 & 574355.06200 & 137103.59400 & 117.6 & 4.7 & 6.1 \\
\hline 299-E33-33 & 574080.12500 & 137301.93800 & 118.6 & 3.8 & 6.4 \\
\hline 299-E33-36 & 574068.56200 & 137239.98400 & 118.4 & 3.6 & 6.4 \\
\hline 299-E33-37 & 574091.50000 & 137185.42200 & 118.6 & 3.9 & 6.3 \\
\hline 299-E34-8 & 574206.43800 & 137249.62500 & 118.8 & 3.5 & 6.1 \\
\hline 299-E34-10 & 574284.37500 & 137224.56200 & 119.1 & 3.3 & 6.4 \\
\hline Bold italic $=$ upgradient wells. & & & & \\
\hline
\end{tabular}

conditions, and in conjunction with ongoing negotiations between DOE and Ecology. Changes to this groundwater monitoring plan necessitated by the replacement well(s) will be documented in an Interim Change Notice or by a groundwater monitoring plan revision.

\subsubsection{Constituent List and Sampling Frequency}

The groundwater in the B-63 trench monitoring wells will be sampled and analyzed for the parameters listed in Table 3.1. In accordance with 40 CFR 265.92, the B-63 trench network wells will be monitored semiannually for total organic carbon, total organic halides, $\mathrm{pH}$, and specific conductance. The wells will be monitored annually for metals and phenols. Anions will be included to detect potential nitrate contamination from surrounding facilities as well as to provide input for charge balance calculations. Alkalinity values will be used with anions and metals to calculate groundwater charge balance. Waterlevel measurements will be taken semiannually.

\subsubsection{Network Evaluation}

The general groundwater flow direction is from west to east across the Hanford Site; artificial recharge to the B Pond system perturbed the general trend. The resulting groundwater mound created a flow direction, still observable near the boundary of the 200 East Area, that is opposite the general west-to-east 


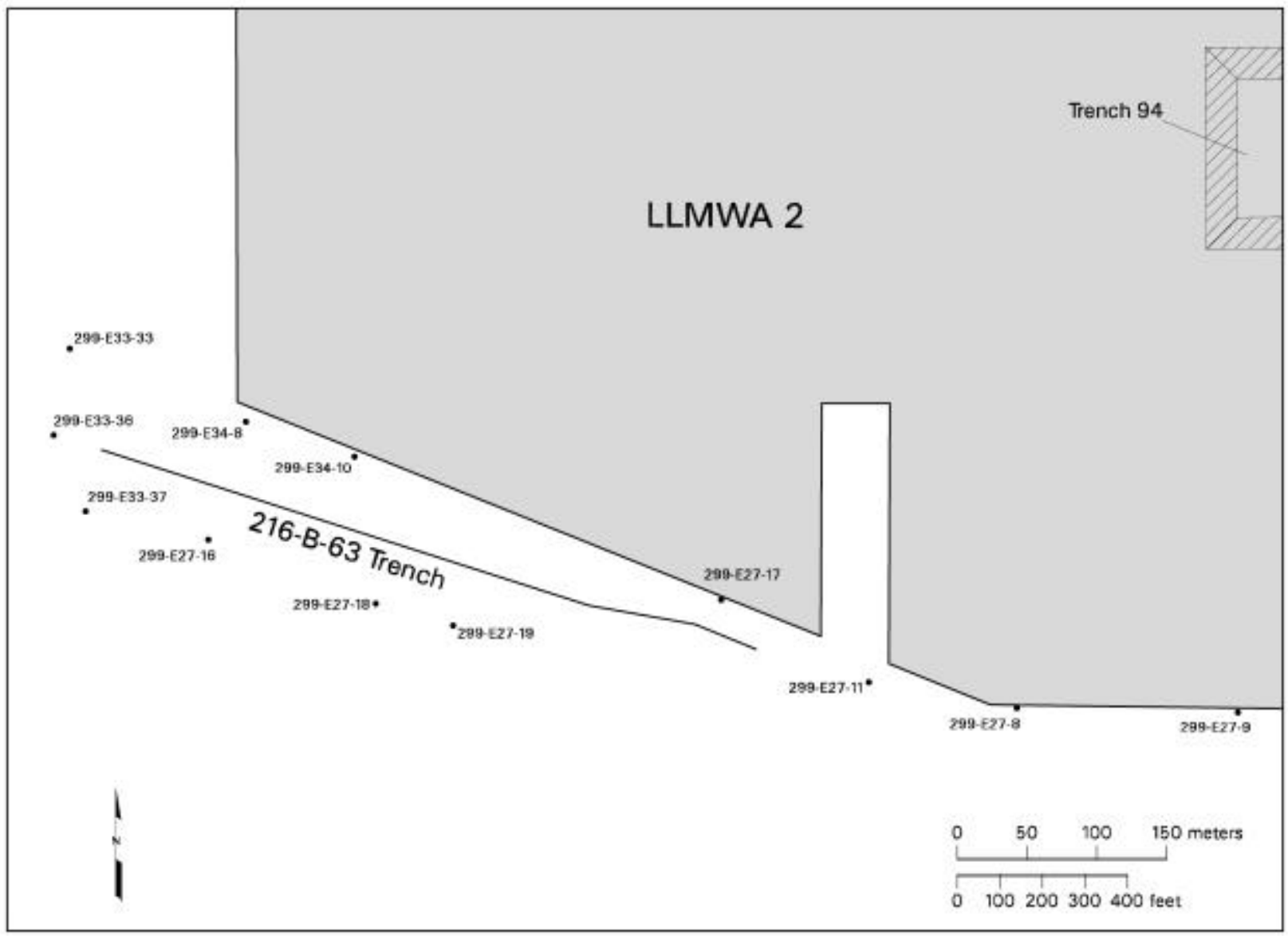

Figure 5.1. Current Network of Groundwater Monitoring Wells for the B-63 Trench

flow direction. The inferred flow is to the southwest (approximately $233^{\circ}$ azimuth [Spane 1999]) beneath the B-63 trench. As the influence of the groundwater mound continues to dimin ish with distance, the general west-to-east flow direction will prevail.

Because groundwater elevations in the Central Plateau were not well documented prior to nuclear processing operations at the Hanford Site, the elevation at which groundwater eventually will stabilize is generally unknown. The groundwater monitoring network as currently configured is re-evaluated at least annually to ensure that it still is adequate to monitor the changing hydrogeologic conditions beneath the trench. Activities that will take place to obtain the necessary information to maintain compliance include

- semiannual groundwater elevation measurements from the B-63 trench network and from wells in the vicinity of the trench

- monitoring efficiency modeling for the current network based on changes in flow conditions

- re-evaluation of the B-63 trench conceptual model and evaluation of geochemical trends. 


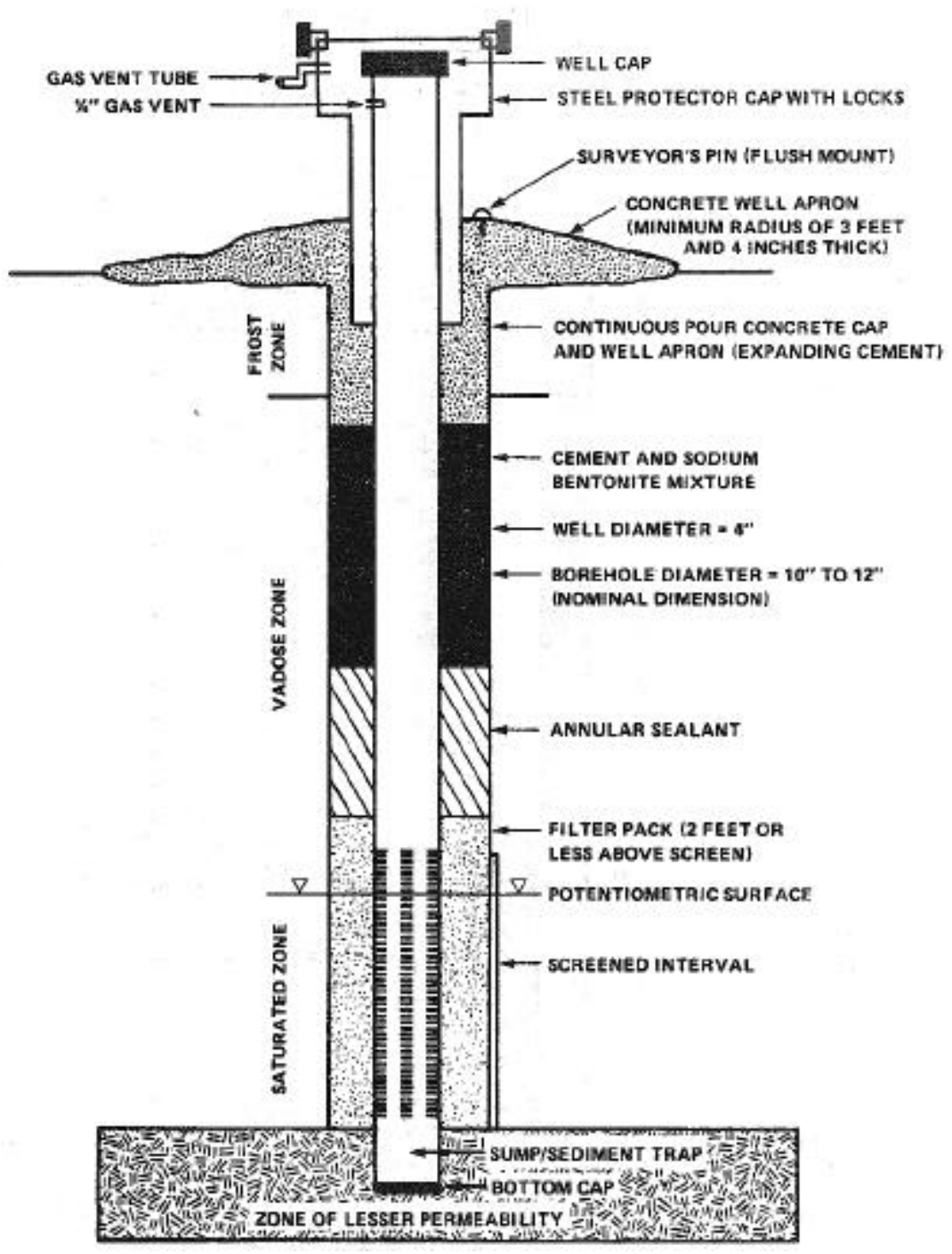

Figure 5.2. Typical Construction, RCRA-Compliant Monitoring Well

An Interim Change Notice or complete revision of the groundwater monitoring plan for the B-63 trench will address changes to the monitoring network.

\subsubsection{Sampling and Analysis Protocol}

Monitoring for the B-63 trench is part of the Hanford Groundwater Monitoring Project. Procedures for groundwater sampling, documentation, sample preservation, shipment, and chain-of-custody requirements are described in subcontractor manuals (currently DFSNW-SSPM-001), and quality requirements are provided in the quality assurance plan. ${ }^{(a)}$ Samples generally are collected after three casing volumes of water have been purged from the well or after field parameters $(\mathrm{pH}$, temperature, specific conductance,

(a) The Hanford Ground-Water Monitoring Project Quality Assurance Project Plan. QA Plan ETD-012, Rev. 2. December 2000. 
and turbidity) have stabilized. For routine groundwater samples, preservatives are added to the collection bottles before their use in the field. Samples to be analyzed for metals are usually filtered in the field so that results represent dissolved metals.

Procedures for field measurements are specified in the subcontractor's or manufacturer's manuals. Analytical methods are specified in contracts with laboratories, and most are standard methods from the U.S. Environmental Protection Agency (EPA) Test Methods for Evaluating Solid Wastes, Physical/ Chemical Methods (EPA 1986b). Alternative procedures meet the guidelines of EPA (1986b, Chapter 10). Analytical methods are described in Chapter 8 of Hartman (2000).

\subsubsection{Quality Assurance and Quality Control}

The quality assurance/quality control (QA/QC) program for the groundwater project ${ }^{(a)}$ is designed to assess and enhance the reliability and validity of groundwater data. The primary quantitative measures or parameters used to assess data quality are accuracy, precision, completeness, and the method detection limit. Qualitative measures include representativeness and comparability. Goals for data representativeness for the groundwater project are addressed qualitatively by the specification of well locations, well construction, sampling intervals, and sampling and analysis techniques in the groundwater monitoring plan for each RCRA facility. Comparability is the confidence with which one data set can be compared to another. The QC parameters are evaluated through laboratory checks (e.g., matrix spikes, laboratory blanks), replicate sampling and analysis, analysis of blind standards and blanks, and interlaboratory comparisons. Acceptance criteria have been established for each of these parameters in the project QA plan ${ }^{(a)}$ based on guidance from the EPA $(1986 \mathrm{a}, \mathrm{b})$. When a parameter is outside the criteria, corrective actions are taken to prevent a future occurrence, and affected data are flagged in the database.

(a) The Hanford Ground-Water Monitoring Project Quality Assurance Project Plan. QA Plan ETD-012, Rev. 2. December 2000. 


\subsection{Data Management, Evaluation, and Reporting}

This chapter describes how groundwater data are stored, retrieved, evaluated, and interpreted. Statistical evaluation methods and reporting requirements also are described.

\subsection{Data Management}

The contract laboratories report analytical results electronically. The results files are loaded into the Hanford Environmental Information System (HEIS) database. Field-measured parameters are entered manually or through electronic transfer. Paper data reports and field records are considered to be the record copies and are stored in the groundwater project files.

Quality control data are evaluated against criteria listed in the project QA plan, ${ }^{(a)}$ and data flags are assigned when the data do not meet these criteria. The data undergo a validation/verification process according to a documented procedure. ${ }^{(b)}$ Under this procedure, scientists familiar with the site hydrogeology screen the data, compare it to historical trends or spatial patterns, and flag the data if they are not representative. Other checks on data may include comparison of general parameters to their specific counterparts (e.g., specific conductance to ions), calculation of charge balances, and comparisons of calculated versus measured values. If data appear anomalous, the project scientist submits a Request for Data Review. ${ }^{(c)}$ If necessary, the laboratory may be requested to check calculations or reanalyze the sample, or the well may be resampled. Results of a review may be used to flag or correct data in the HEIS.

\subsection{Interpretation}

After data are validated and verified, the acceptable data are used to interpret groundwater conditions at the site. Data interpretation is accomplished using the following techniques:

- Hydrographs graph water levels against elapsed time to determine decreases, increases, and seasonal or man-made fluctuations in groundwater levels.

- Water-table maps use water-table elevations from multiple wells to construct contour maps to estimate flow directions. Groundwater flow is assumed to be perpendicular to lines of equal potential.

(a) Hanford Ground-Water Monitoring Project Quality Assurance Project Plan, QA Plan ETD-012, Rev. 2, December 2000, or most recent revision. Pacific Northwest National Laboratory, Richland, Washington.

(b) Procedure QC-5, Groundwater Data Validation Process in PNL-MA-567. Pacific Northwest National Laboratory, Richland, Washington.

(c) Procedure DA-3, Data Review Procedure in PNL-MA-567. Pacific Northwest National Laboratory, Richland, Washington. 
- Trend plots graph concentrations of chemical or radiological constituents against elapsed time to determine increases, decreases, and fluctuations. Trend plots may be used in tandem with hydrographs and/or water-table maps to determine if concentrations relate to changes in water level or in groundwater flow directions.

- Plume maps map distributions of chemical or radiological constituents areally in the aquifer to determine extent of contamination. Changes in plume distribution over time aid in determining movement of plumes and direction of flow.

- Contaminant ratios sometimes can be used to distinguish between different sources of contamination.

\subsection{Statistical Evaluation}

The goal of RCRA detection monitoring is to determine if the B-63 trench has affected groundwater quality. This is determined based on the results of a statistical test. According to 40 CFR 265.92 [and, by reference, WAC 173-303-400(3)], the owner/operator of an interim-status hazardous waste facility must establish initial background concentrations for the contamination indicator parameters: specific conductance, $\mathrm{pH}$, total organic carbon, and total organic halides. This has been done for the B-63 trench by obtaining at least four replicate measurements for each parameter from each well quarterly for 1 year. Data from the upgradient well(s) were used to determine the initial background arithmetic mean and variance.

Monitoring data collected after the first year are compared with the initial background data to determine if there is an indication that contamination may have occurred. A t-test is required to make this determination [40 CFR 265.93(b)]. A recommended method is the averaged replicate t-test method described in Appendix B of the RCRA Groundwater Monitoring Technical Enforcement Guidance Document (EPA 1986a). The averaged replicate t-test method for each contamination indicator parameter is calculated as

$$
\mathrm{t}=\left(\overline{\mathrm{x}}_{\mathrm{i}}-\overline{\mathrm{x}}_{\mathrm{b}}\right) / \mathrm{S}_{\mathrm{b}} * \sqrt{1+1 / \mathrm{n}_{\mathrm{b}}}
$$

where $\mathrm{t}=$ test statistic

$\overline{\mathrm{X}_{\mathrm{i}}}=$ average of replicates from the $\mathrm{i}^{\text {th }}$ monitoring well

$\overline{\mathrm{x}}_{\mathrm{b}}=$ background average

$\mathrm{S}_{\mathrm{b}}=$ background standard deviation

$\mathrm{n}_{\mathrm{b}}=$ number of background replicate averages.

A test statistic larger than the Bonferroni critical value, $t_{c}$, (i.e., $t>t_{c}$ ) indicates a statistically significant probability of contamination. These Bonferroni critical values depend on the overall false-positive rate required for each sampling period (i.e., $1 \%$ for interim status), the total number of wells in the monitoring network, and the number of degrees of freedom $\left(\mathrm{n}_{\mathrm{b}}-1\right)$ associated with the background standard deviation. Because of the nature of the test statistic in Equation (6.1), results to be compared to 
background do not contribute to the estimate of the variance. The test can be reformulated, without prior knowledge of the results of the sample to be compared to background (i.e., $\overline{\mathrm{x}}_{\mathrm{i}}$ ), in such a way that a critical mean, CM, can be obtained:

$$
\begin{aligned}
& \mathrm{CM}=\overline{\mathrm{x}}_{\mathrm{b}}+\mathrm{t}_{\mathrm{c}} * \mathrm{~S}_{\mathrm{b}} * \sqrt{\left(1+1 / \mathrm{n}_{\mathrm{b}}\right)} \quad \text { (one-tailed) } \\
& \mathrm{CM}=\overline{\mathrm{x}}_{\mathrm{b}} \pm \mathrm{t}_{\mathrm{c}} * \mathrm{~S}_{\mathrm{b}} * \sqrt{\left(1+1 / \mathrm{n}_{\mathrm{b}}\right)} \quad \text { (two-tailed) }
\end{aligned}
$$

If downgradient data exceed the $\mathrm{CM}$, they are determined to be statistically different from background. For $\mathrm{pH}$, a two-tailed CM (or critical range) is calculated, and downgradient data beyond the range are considered to be statistically different from background. If a statistical exceedance is detected, the well will be resampled to determine if the originally detected increase (or $\mathrm{pH}$ decrease) was a result of laboratory or measurement error (verification sampling). If verification sampling confirms the exceedance, the owner/operator must notify Ecology within 7 days and submit a groundwater quality assessment plan within 15 days following the notification [40 CFR 265.93(d)]. The goal of the assessment monitoring program is to determine if dangerous waste or dangerous waste constituents from the facility have entered the groundwater and, if so, to determine their concentration and the rate and extent of migration in groundwater [40 CFR 265.93(d)].

Critical mean values for the B-63 trench are presented in Table 3.2. Upgradient data are evaluated each year to determine if CM values should be recalculated because of changes in upgradient groundwater chemistry. Updated values are published in the annual groundwater monitoring report (e.g., Hartman et al. 2002).

\subsection{Reporting}

Chemistry and water-level data are reviewed at least quarterly and are available in the HEIS. Interpretive reports are issued annually in March (e.g., Hartman et al. 2002). Reporting requirements are listed in Table 6.1. 
Table 6.1. Reports Required for Compliance with 40 CFR 265, Subpart F, for Groundwater Monitoring

\begin{tabular}{|c|c|c|c|}
\hline Submittal & Submittal Period & Reporting Vehicle & $\begin{array}{l}\text { Regulatory } \\
\text { Requirement }\end{array}$ \\
\hline $\begin{array}{l}\text { First year of sampling: concentrations of } \\
\text { interim primary drinking water constitu- } \\
\text { ents, identifying those that exceed limits }\end{array}$ & Quarterly & Complete $^{(a)}$ & $\begin{array}{l}40 \text { CFR } \\
265.94(a)(2)(i)\end{array}$ \\
\hline $\begin{array}{l}\text { Concentration and statistical analyses of } \\
\text { groundwater contamination indicator } \\
\text { parameters, noting significant differences } \\
\text { in upgradient wells }\end{array}$ & $\begin{array}{l}\text { Annually, by } \\
\text { March } 1 \text { of } \\
\text { following year }\end{array}$ & $\begin{array}{l}\text { Hanford groundwater } \\
\text { monitoring report (e.g., } \\
\text { Hartman 2000) }\end{array}$ & $\begin{array}{l}40 \text { CFR } \\
265.94(\mathrm{a})(2)(\mathrm{ii})\end{array}$ \\
\hline $\begin{array}{l}\text { Results of groundwater surface elevation } \\
\text { evaluation and description of response if } \\
\text { appropriate }\end{array}$ & $\begin{array}{l}\text { Annually, by } \\
\text { March } 1 \text { of } \\
\text { following year }\end{array}$ & $\begin{array}{l}\text { Hanford groundwater } \\
\text { monitoring report }\end{array}$ & $\begin{array}{l}40 \text { CFR } \\
265.94(a)(2)(\text { iii })\end{array}$ \\
\hline $\begin{array}{l}\text { Outline for groundwater quality assessment } \\
\text { program }\end{array}$ & $\begin{array}{l}\text { Within one year } \\
\text { after effective date } \\
\text { of regulations }\end{array}$ & $\begin{array}{l}\text { Chapter } 7 \text { of this } \\
\text { document }\end{array}$ & 40 CFR 265.93(a) \\
\hline Notification of statistical exceedance ${ }^{(b)}$ & $\begin{array}{l}\text { Within } 7 \text { days of } \\
\text { verification }\end{array}$ & Letter to Ecology & 40 CFR 265.93(c) \\
\hline Assessment plan ${ }^{(\mathrm{b})}$ & $\begin{array}{l}\text { Within } 15 \text { days of } \\
\text { notification }\end{array}$ & $\begin{array}{l}\text { PNNL document or } \\
\text { letter }\end{array}$ & 40 CFR 265.93(d) \\
\hline $\begin{array}{l}\text { Determinations under assessment } \\
\text { program }^{(b)}\end{array}$ & $\begin{array}{l}\text { As soon as } \\
\text { technically feasible; } \\
\text { annually thereafter }\end{array}$ & $\begin{array}{l}\text { PNNL document, letter, } \\
\text { or Hanford groundwater } \\
\text { monitoring report }\end{array}$ & $\begin{array}{l}40 \text { CFR 265.93(d)(5) } \\
\text { and 265.94(b) }\end{array}$ \\
\hline \multicolumn{4}{|c|}{$\begin{array}{l}\text { (a) Requirement was fulfilled during first year of sampling via published reports. Quarterly submittal of data } \\
\text { continues via the HEIS. } \\
\text { (b) Required if exceedance occurs and is verified. }\end{array}$} \\
\hline
\end{tabular}




\subsection{Outline for Assessment Monitoring Plan}

This chapter presents a basic outline for an assessment monitoring plan, as required by 40 CFR 265.93(a). The assessment program must be capable of determining whether dangerous waste or dangerous waste constituents have entered the groundwater, along with their concentration and rate and extent of migration.

If an indicator parameter at a downgradient well significantly exceeds the background value, an assessment plan will be prepared and submitted to Ecology (see Section 6.3). The plan will include the following information:

- description of the approach to determine if dangerous waste or dangerous waste constituents from the facility have entered the groundwater or if the exceedance was caused by other sources (false positive rationale)

- description of the investigative approach to fully characterize rate and extent of contaminant migration

- number, locations, and depths of wells in the monitoring network

- sampling and analytical methods used

- data evaluation procedures

- an implementation schedule.

An outline for the assessment plan is presented in Figure 7.1.

The assessment determinations will be made as soon as technically feasible, and a report of the findings will be sent to Ecology. The determinations then will be updated annually as required by 40 CFR 265.94(b). 


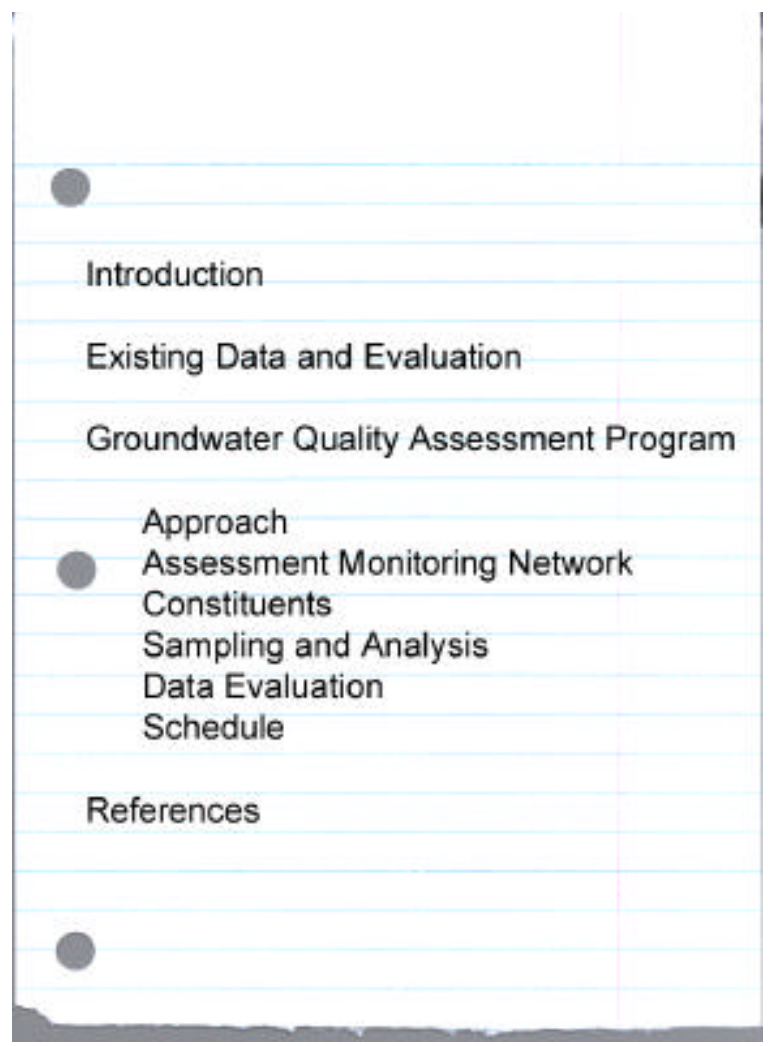

Figure 7.1. Outline for Groundwater Quality Assessment Monitoring Plan 


\subsection{References}

Resource Conservation and Recovery Act (RCRA) of 1976, as amended, Public Law 94-580, 90 Stat. 2795, 42 USC 6901 et seq.

40 CFR 265. 1980. U.S. Environmental Protection Agency, "Interim Status Standards for Owners of Hazardous Waste Treatment, Storage, and Disposal Facilities." U.S. Code of Federal Regulations.

Washington Administrative Code (WAC). 1973. "Minimum Standards for Construction and Maintenance of Wells." WAC 173-160, Olympia, Washington.

Washington Administrative Code (WAC). 1982. "Interim Status Facility Standards." WAC 173-303-400, Olympia, Washington.

Fayer MJ, and TB Walters. 1995. Estimated Recharge Rates at the Hanford Site. PNL-10285, Pacific Northwest National Laboratory, Richland, Washington.

Graham MJ, MD Hall, SR Strait, and WR Brown. 1981. Hydrology of the Separations Area. RHO-ST-42, Rockwell Hanford Operations, Richland, Washington.

Hartman MJ, ed. 2000. Hanford Site Groundwater Monitoring: Setting, Sources, and Methods. PNNL-13080, Pacific Northwest National Laboratory, Richland, Washington.

Hartman MJ, LF Morasch, and WD Webber, eds. 2002. Hanford Site Groundwater Monitoring for Fiscal Year 2001. PNNL-13788, Pacific Northwest National Laboratory, Richland, Washington.

Jacobs MC, and DL Uebelacker. 1971. Radioactive Liquid Wastes Discharged to Ground in the 200 Areas During 1970. ARH-2015, Pt. 3, Atlantic Richfield Hanford Company, Richland, Washington.

Lindsey KA, BN Bjornstad, JW Lindberg, and KM Hoffman. 1992. Geologic Setting of the 200 East Area: An Update. WHC-SD-EN-TI-012, Westinghouse Hanford Company, Richland, Washington.

Richland Operations Office. 2000. 200-CS-1 Operable Unit RI/FS Work Plan and RCRA TSD Unit Sampling Plan. DOE/RL-99-44, U.S. Department of Energy, Richland Operations Office, Richland, Washington.

Spane, FA. 1999. Evaluation of Barometric Fluctuations on Well Water-Level Measurements and Aquifer Test Data. PNNL-13078, Pacific Northwest National Laboratory, Richland, Washington.

Sweeney MD. 1995. Interim Status Groundwater Monitoring Plan for the 216-B-63 Trench, Rev. 1. WHC-SD-EN-AP-165, Rev. 1, Westinghouse Hanford Company, Richland, Washington. 
U.S. Environmental Protection Agency (EPA). 1986a. RCRA Groundwater Monitoring Technical Enforcement Guidance Document. OSWER 9950.1, U.S. Environmental Protection Agency, Washington, D.C.

U.S. EnvironmentalProtection Agency (EPA). 1986b. Test Methods for Evaluating Solid Wastes: Physical/Chemical Methods. $3^{\text {rd }}$ ed. SW-846, Office of Solid Waste and Emergency Response, U.S. Environmental Protection Agency, Washington, D.C.

Williams BA, BN Bjornstad, R Schalla, and WD Webber. 2000. Revised Hydrogeology for the Suprabasalt Aquifer System, 200-East Area and Vicinity, Hanford Site, Washington. PNNL-12261, Pacific Northwest National Laboratory, Richland, Washington.

Wilson CR, CM Einberger, RL Jackson, and RB Mercer. 1992. "Design of Groundwater Monitoring Networks Using the Monitoring Efficiency Model (MEMO).” Groundwater 30(6):965-970. 


\section{Appendix A}

As-Built Drawings for the

216-B-63 Trench Network Wells 


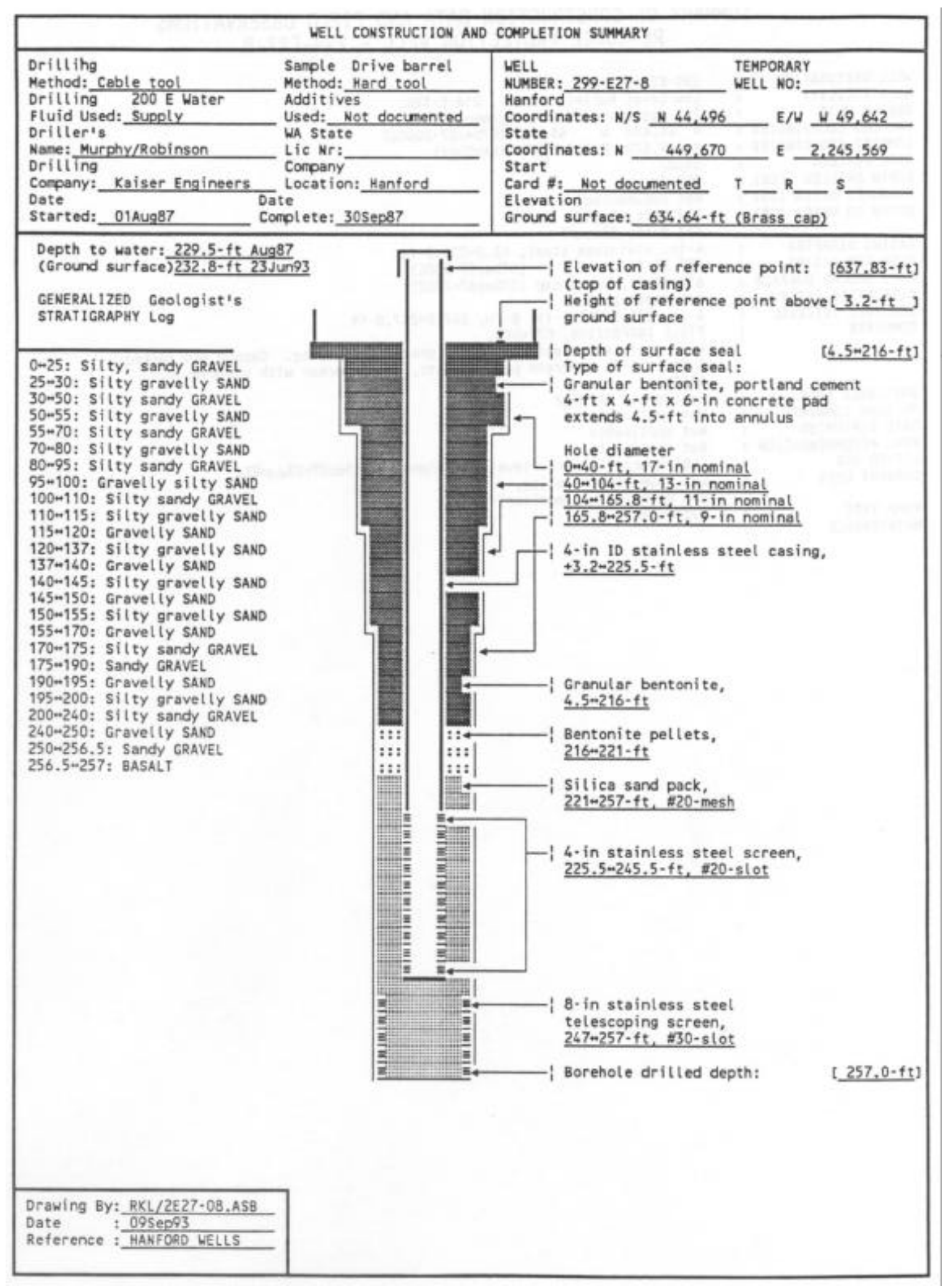




\section{SUMMARY OF CONSTRUCTION DATA AND FIELD OBSERVATIONS RESOURCE PROTECTION WELL - 299-E27-8}

WELL DESIGMATION
RCRA FACILITY
CERCLA UNIT
HANFCRO COORDINATES :
LAMBERT COORDINATES :
DATE DRILLED
DEPTH ORILLED (GS)
MEASUREO DEPTH (GS)
DEPTH TO WATER (GS)
CASING DIAMETER
ELEV TOP CASING
ELEV GROUND SURFACE :
PERFCRATED INTERVAL
SCREENEO INTERVAL
COMMENTS
AVAILABLE LOGS
TV SCAN CONMENTS
DATE EVALUAED
EVAL RECOMNENDATION :
LISTED USE
OURRENT USER
PUMP TYPE
MAINTENANCE

$299-E 27-8$

Low Level Burial Grounds, 218-E-12B

200 Aggregate Area Manogement Study

N 44,496 W 49,642 [07DecB7-2000E]

N 449,670 E 2,245,569 [HANCONV]

Sep87

$257-\mathrm{ft}$

Not documented

$229.5-\mathrm{ft}$, Aug 87 .

232.8- $\mathrm{ft}, 23$ Junǵ3

4-in, stainless steel, $+3.2+225.5-\mathrm{ft}$.

637.83-ft [OTDec87-200E]

$634.64-\mathrm{ft}$, Brass cap [O70ec87-200E]

Not applicable

4-in, 225.5-245.5-ft; 8-in, 247.0-257.0-ft

FIELD INSPECTION, 07Feb90,

4-in stainless steel casing, no protective casing. Capped and locked.

$4=\mathrm{ft}$ by $4-\mathrm{ft}$ concrete pad, 4 posts, brass marker with stamped 10 .

OTHER:

Geologist, Driller

Not applicable

Not applicable

Not applicable

LLBG quarterly water level measurement, 010ec87-23Jun93;

WHC ESAM RCRA sampling,

PNL sitewide $w / l$ monitoring

Hydrostar 


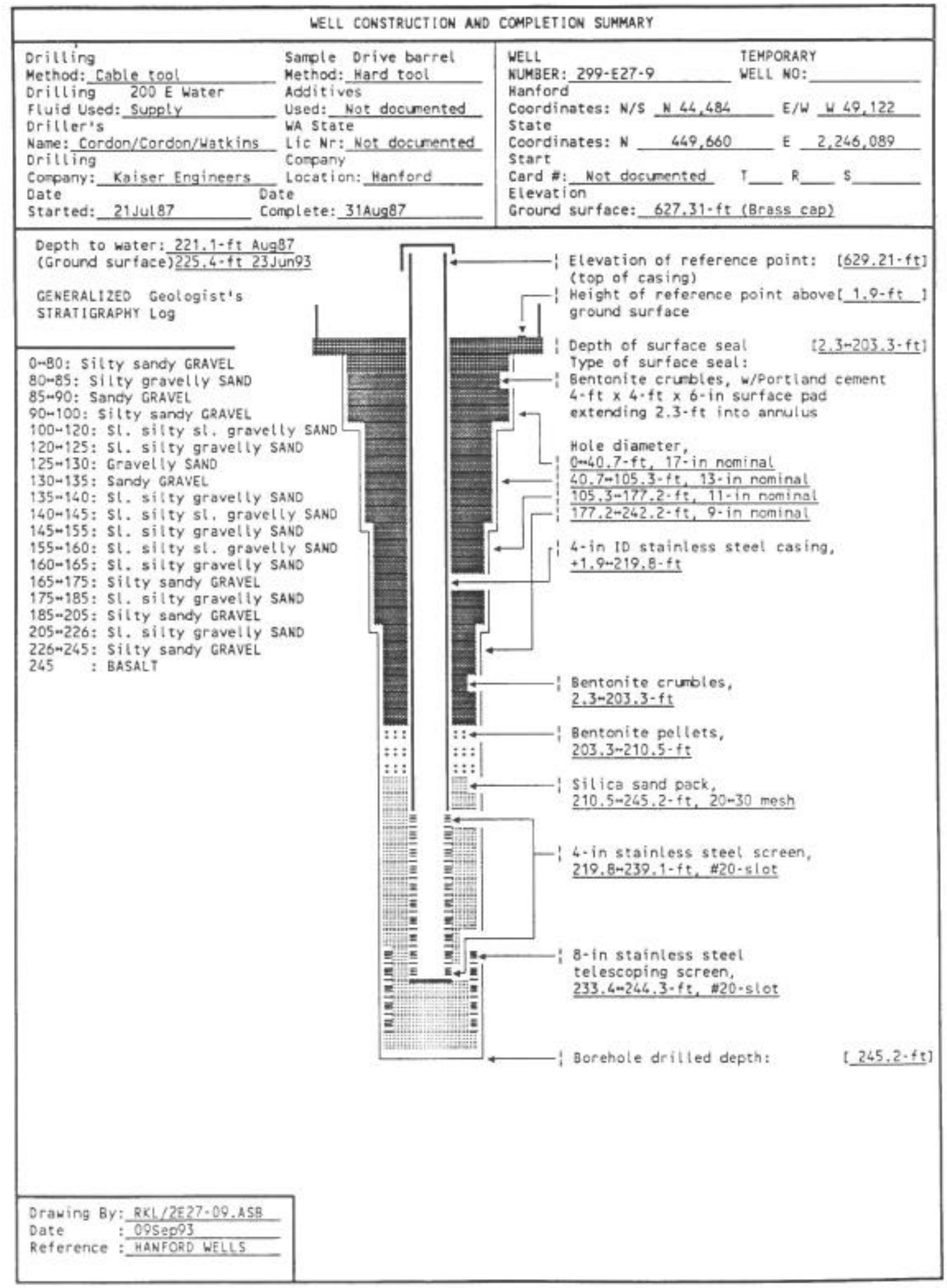




\section{SUMMARY OF CONSTRUCTION DATA AND FIELD OBSERVATIONS RESOURCE PROTECTION WELL - 299-E27-9}

WELL DESIGNATION
RCRA FACILITY
CERCLA UNIT
HANFORD COCRDINATES :
LAMBERT COORDINATES :
DATE DRILLED
DEPTH DRILLED (GS)
MEASURED DEPTH (GS) :
DEPTH TO WATER (GS) :
CASING DIAMETER
ELEV TOP CASING
ELEV GROUND SURFACE :
PERFORATED INTERVAL :
SCREENED INTERVAL :
COMMENTS

AVATLABLE LOGS

TV SCAN COMMENTS

DATE EVALUATED

EVAL RECOMMENDATION

LISTED USE

CURRENT USER

PUMP TYPE

MAINTENANCE
299-E27-9

Low Level Burial Grounds, 218-E-128

200 Aggregate Area Management study

N 46,484 W 49,122 [OTDec87-200E]

N 449,660 E $2,246,089$ [HANCONV]

Aug87

$245.2 \cdot \mathrm{ft}$

Not documented

221.1-ft, AugB7,

$225.6-\mathrm{ft}, 23$ Jungs

4-in, stainless steet, $+1.9-219.8-\mathrm{ft}$.

$629.21-\mathrm{ft}$ [O7Dec87-200E]

$627.31-\mathrm{ft}$, Brass cap [07Dec87-200E]

Not applicable

4 -in, $219.8 \mathrm{~m} 239,1-\mathrm{ft} ; \mathrm{B}-\mathrm{in}, 233,4 \mathrm{~m}-244.3-\mathrm{ft}$

FIELD IMSPECTION, 07Feb90

4-in stainless steel casing, no protective casing. Capped and locked.

$4-\mathrm{ft}$ by $4-\mathrm{ft}$ concrete pad, 4 posts, brass marker with stanped 10 .

OTHER;

Geologist, Drilter

Not applicable

Not appl icable

Not applicable

LLBG quarterly water level measurement, 01Dec87-23jung3;

WHC ESBM W/l monitoring and RCRA sampl ing.

PNL sitewide sampling and $w / l$ monitoring 93

Hydrostar 


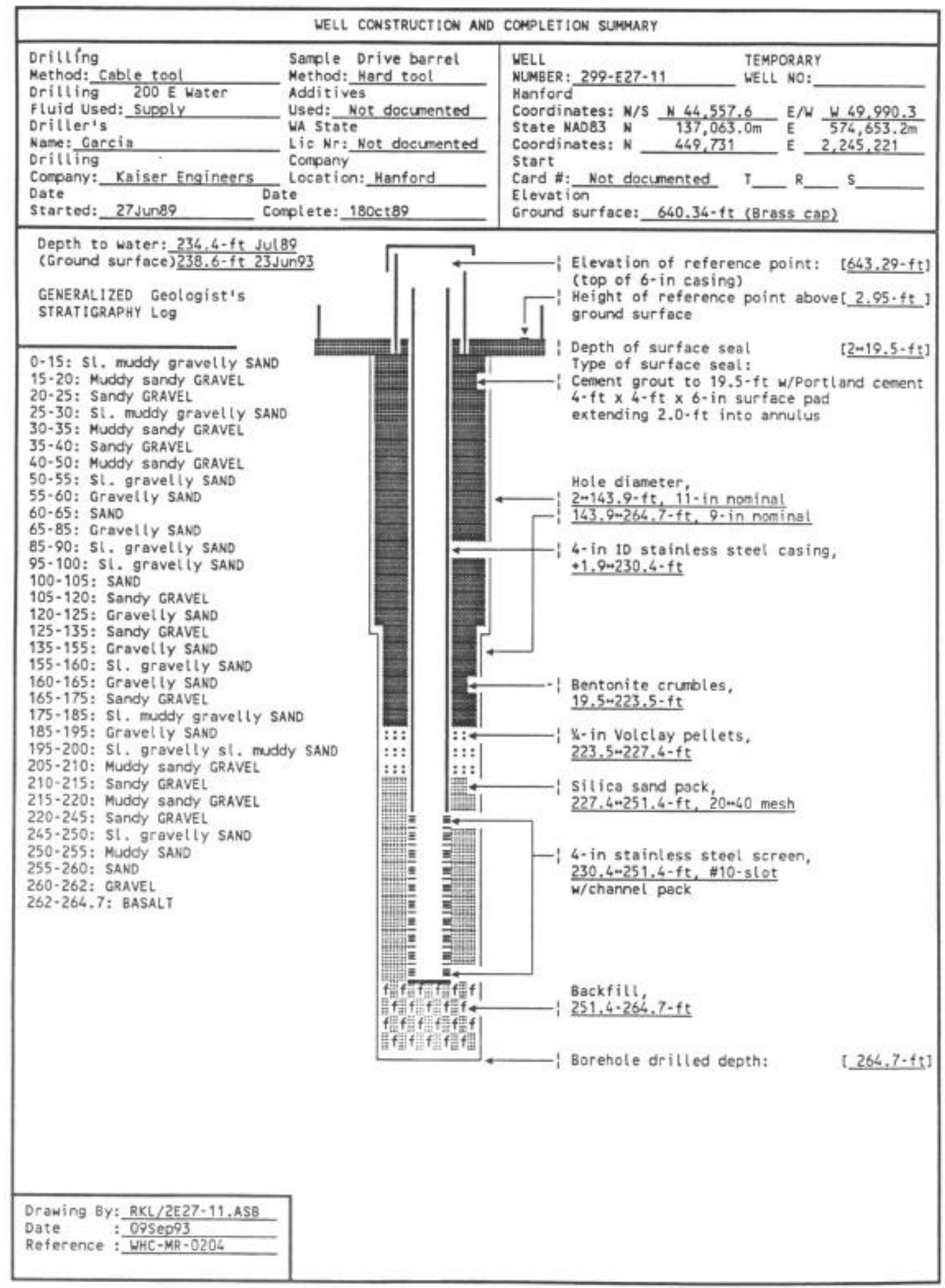




\section{SUMMARY OF CONSTRUCTION DATA AND FIELD OBSERVATIONS RESOURCE PROTECTION WELL - 299-E27-11}

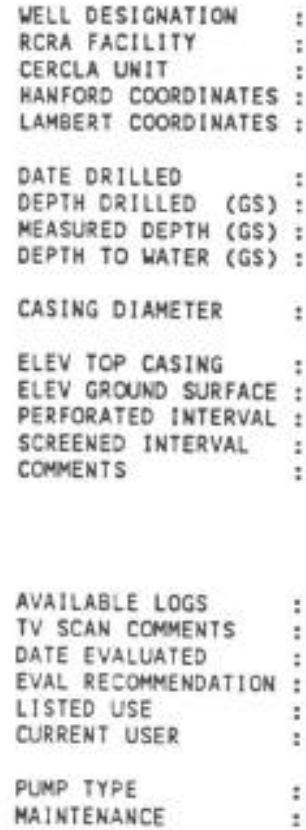

299-E27-11

Low Level Burial Grounds, 218-E-12B 200 Aggregate Area Management study

N 44,557.6 W $49,990.3$ [12 Jun90-200E]

N 449,731 E $2,245,221$ [HANCONV]

N 137, 063.0n E $574,653.2 \mathrm{~m}$ [12Jun90-NAD83]

Oet89

$264.7-f t$

Not documented

$234.4-\mathrm{ft}$, Jut 89

238.6- $\mathrm{ft}, 23$ Jung

$4-\mathrm{in}$, stainless steel, +1.9-230.4-ft.

$6-i n$ stainless steel, $+2.95 * 0.5-f t$

$643.29-\mathrm{ft}$, [12Jun90-200E]

$640.34-\mathrm{ft}$, Brass cap [12Jun90-200E]

Not applicable

4-in stainless steel with channel pack, 230.4*251.4-ft

FIELD INSPECTION, O7Feb90,

4-in stainless steel casing, 6-in protective casing, Capped and locked. $4-\mathrm{ft}$ by $4-\mathrm{ft}$ concrete pad, 4 posts, brass marker with stamped 10 . Not in radiation zone.

OTHER;

Geologist, Dritler

Not applicable

Not applicable

hot appl icable

LLBG quarterly water level measurement, 010 ec89u23 Jun93;

WHC ES\&M W/L monitoring and RCRA sampling,

PNL sitewide sampling 93

Hydrostar 


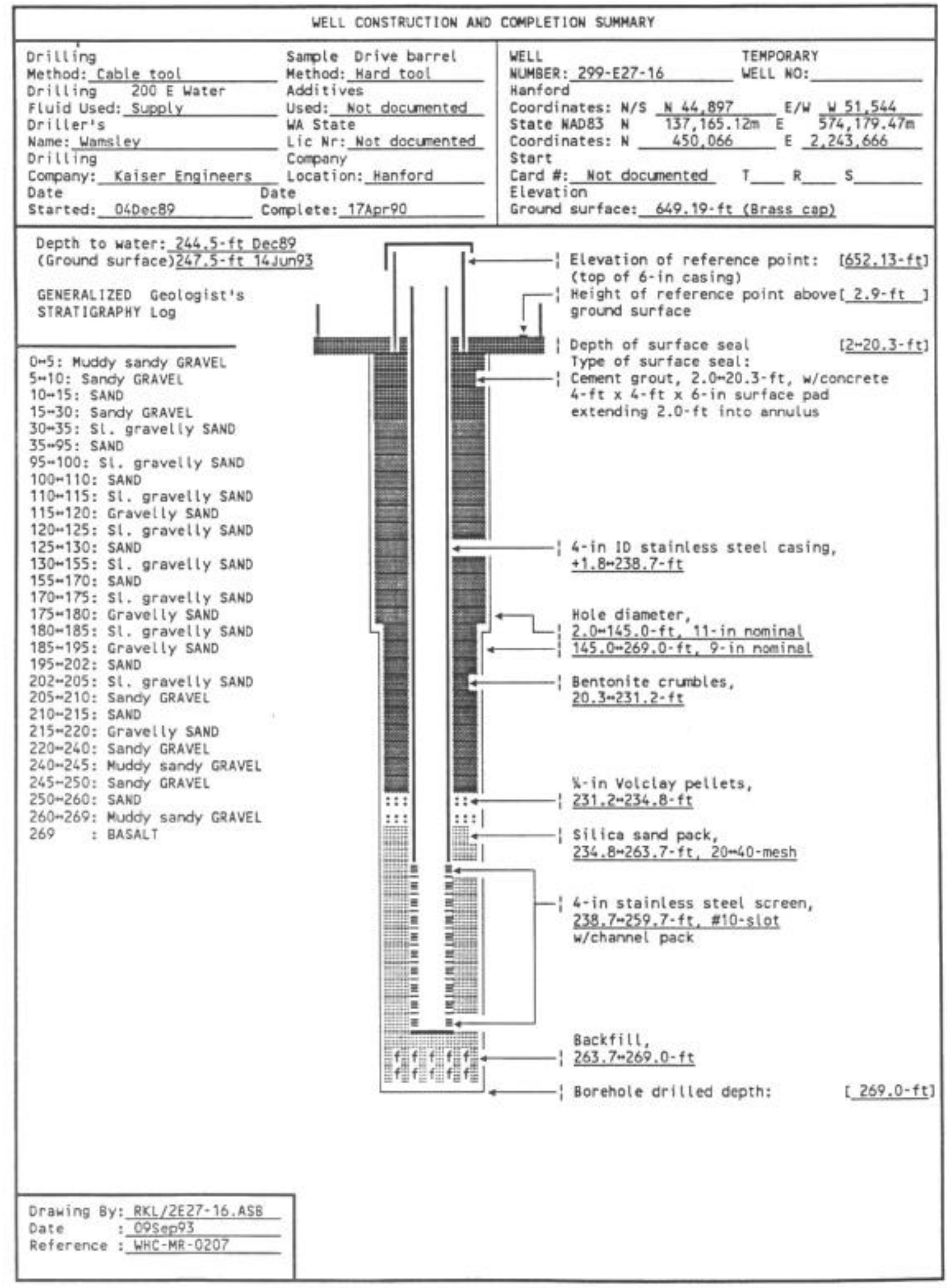


SUMMARY OF CONSTRUCTION DATA AND FIELD OBSERVATIONS RESOURCE PROTECTION WELL - 299-E27-16

\begin{tabular}{|c|c|c|}
\hline WELL DESIGNATION & : & $2-E 27-16$ \\
\hline RCRA FACILITY & : & $216-8-63$ Trench \\
\hline CERCLA UKIT & : & 200 Aggregate Area Management Study \\
\hline HAMFORD COORDINATES & : & N 44,897 H 51,544 [19Apr90-200E] \\
\hline LAMBERT COORDINATES & : & 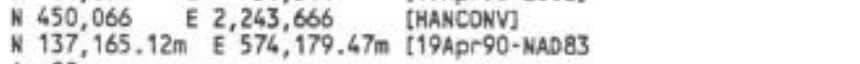 \\
\hline DATE DRILLED & : & Apr90 \\
\hline DEPTH DRILLED (GS) & : & $269.0-\mathrm{ft}$ \\
\hline MEASURED DEPTH (GS) & : & $251.7-\mathrm{ft}, 27$ Aug93 \\
\hline DEPTH TO WATER (GS) & : & $\begin{array}{l}244.5-\mathrm{ft} \text {, Dec89; } \\
247.5-\mathrm{ft}, 14 \text { Jungs }\end{array}$ \\
\hline CASING DIAMETER & : & $\begin{array}{l}4-\text { in, stainless steel, }+1.8+238.7-\mathrm{ft} ; \\
6-\text { in, stainless steel, }+2.90^{-} 0.5-\mathrm{ft}\end{array}$ \\
\hline ELEV TOP CASING & $t$ & $652.13-\mathrm{ft} \quad$ [19Apr90-200E] \\
\hline ELEV GROUND SURFACE & : & $649.19-\mathrm{ft}$, Brass cap [19Apr90-200E] \\
\hline PERFORATED INTERVAL & : & Not applicable \\
\hline SCREENED INTERVAL & : & $238.7-259.7-\mathrm{ft}, 4-$ in stainless steel with channel pack, \\
\hline CONMENTS & : & $\begin{array}{l}\text { F1ELD INSPECTIOH, } 27 \text { Aug93; } \\
4 \text { and } 6-\text { in stainiess steel casing. } \\
4-\mathrm{ft} \text { by } 4-\mathrm{ft} \text { concrete pad, } 4 \text { posts, } 1 \text { removable. } \\
\text { Capped and locked, brass cap in pad with well to. } \\
\text { Not in radiation zone. } \\
\text { OTHER; }\end{array}$ \\
\hline AVATLABLE LOGS & : & Geologist, Driller \\
\hline TV SCAN COMMENTS & : & Not applicable \\
\hline DATE EVALUATED & : & Not applicable \\
\hline EVAL RECOMMENDATION & : & Kot applicable \\
\hline $\begin{array}{l}\text { LISTED USE } \\
\text { CURRENT USER }\end{array}$ & : & $\begin{array}{l}\text { B.63 Trench quarterly water level measurement, } 20 \text { Nov90-14Jun93; } \\
\text { WHC ES\&M w/l monitoring and RCRA sampling, } \\
\text { PNL sitewide sampling } 93\end{array}$ \\
\hline $\begin{array}{l}\text { PUMP TYPE } \\
\text { MAINTENANCE }\end{array}$ & t & Hydrostar \\
\hline MAINTENANC & & \\
\hline
\end{tabular}




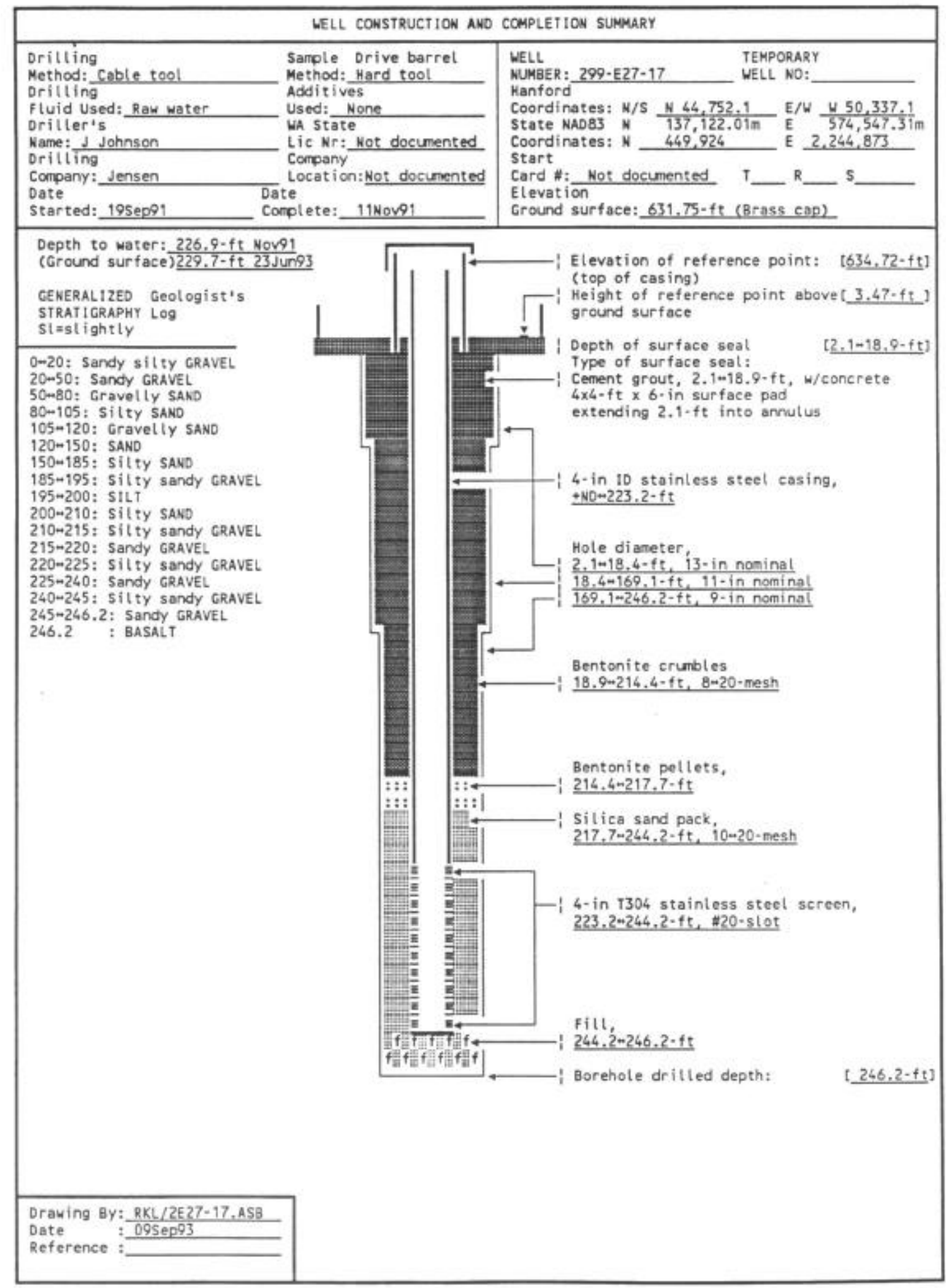


SUMMARY OF CONSTRUCTION DATA AND FIELD OBSERVATIONS RESOURCE PROTECTION WELL - 299-E27-17

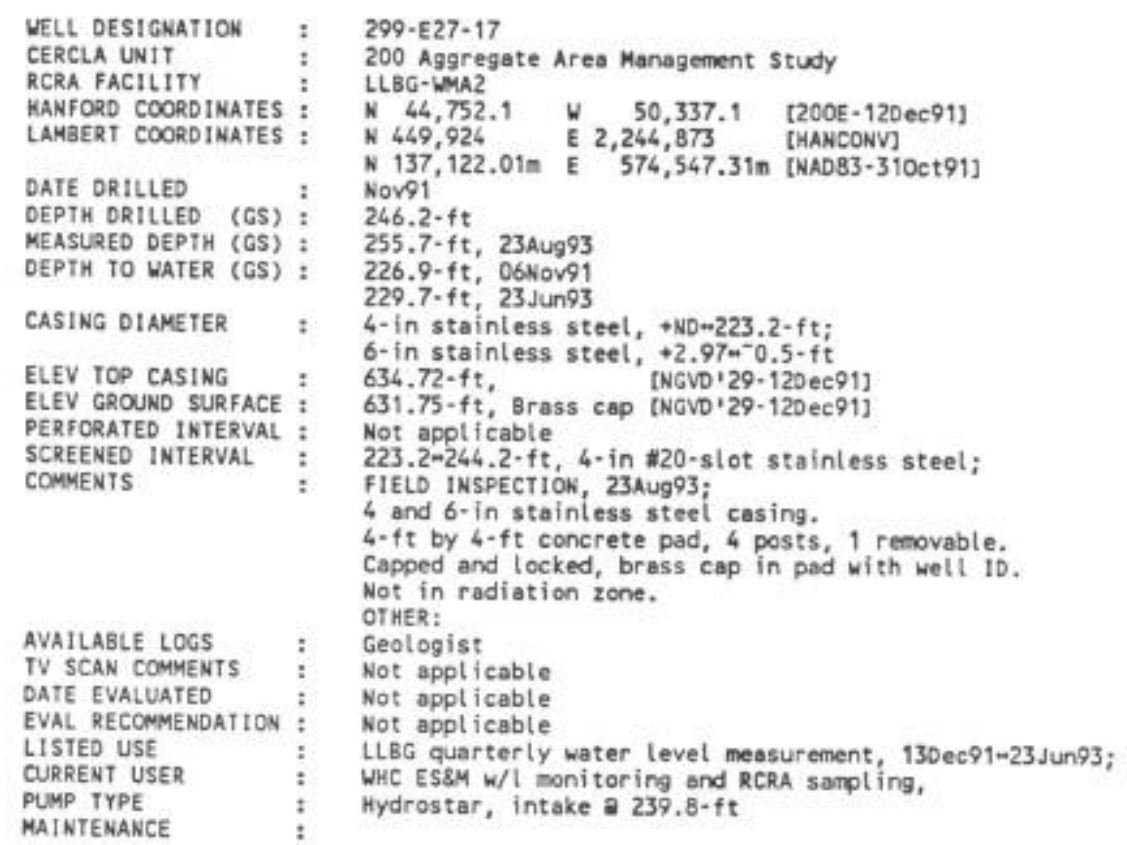




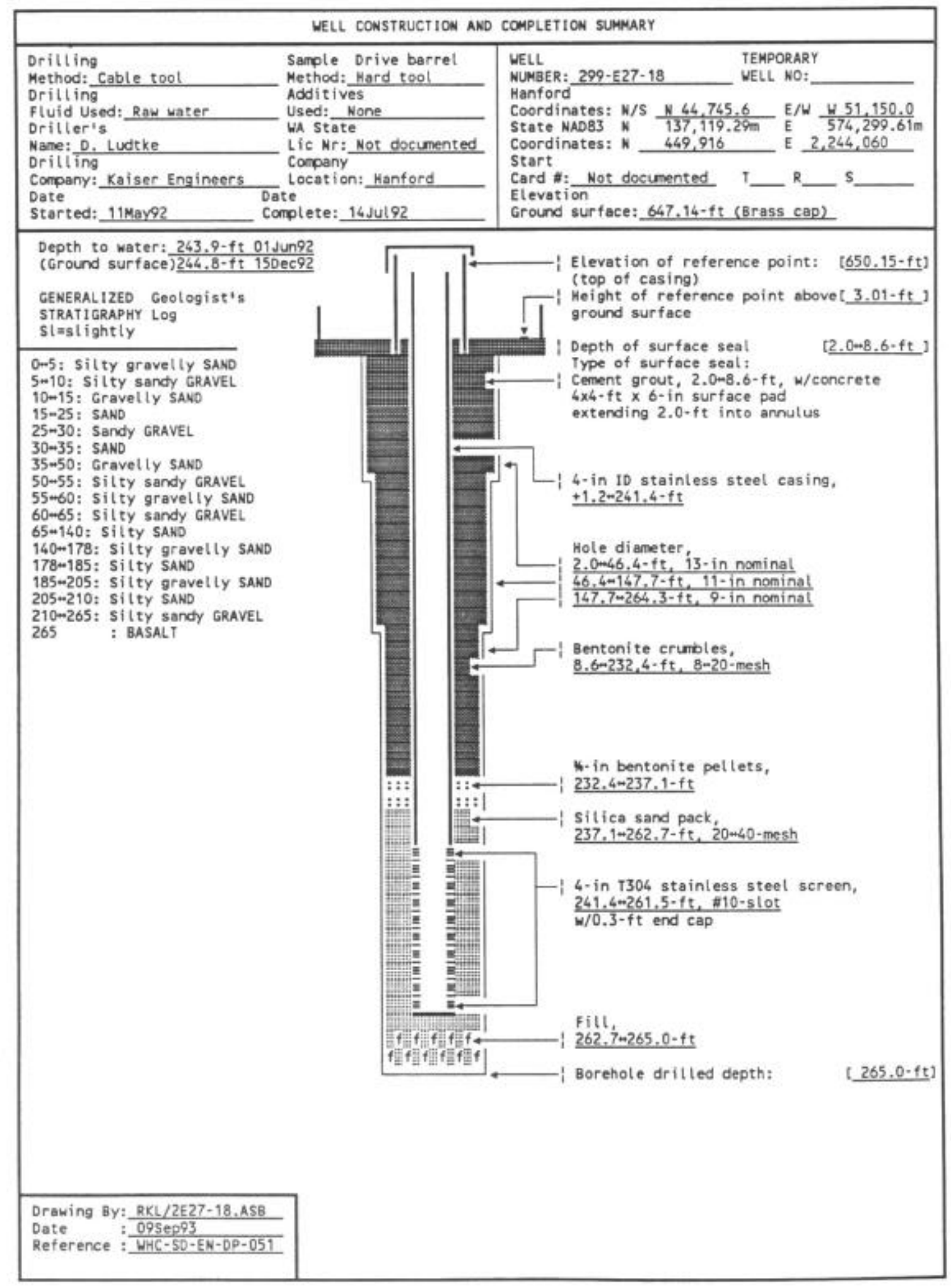




\section{SUMMARY OF CONSTRUCTION DATA AND FIELD OBSERVATIONS RESOURCE PROTECTION WELL - 299-E27-18}

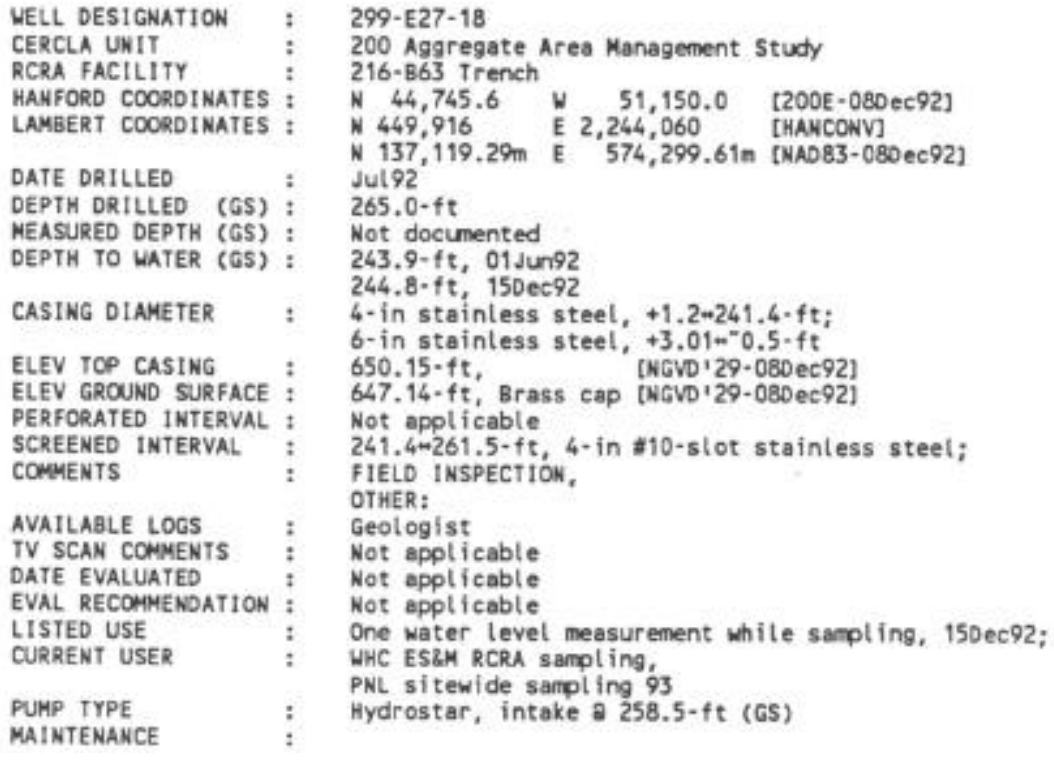




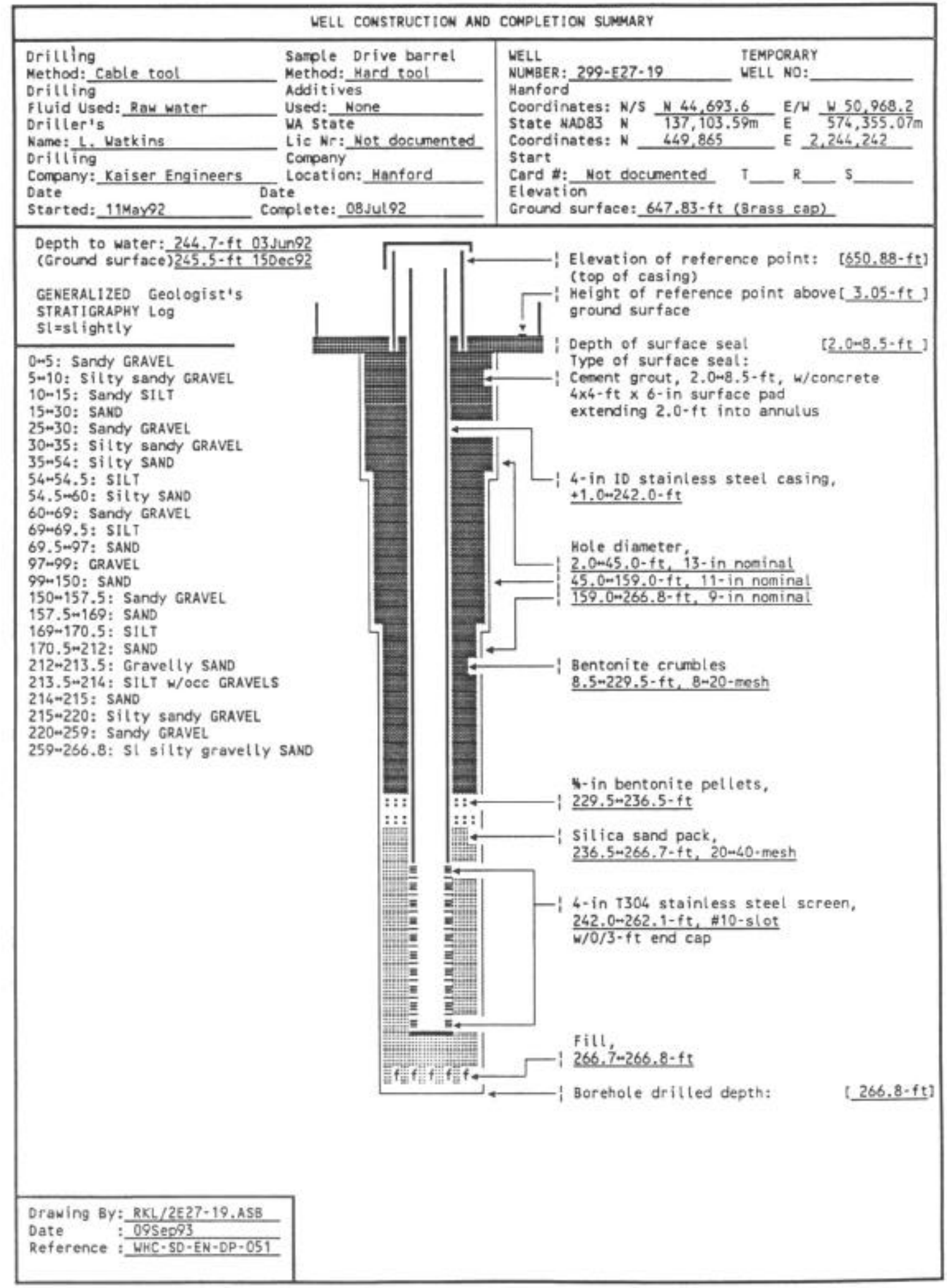


SMMARY OF CONSTRUCTION DATA AND FIELD OBSERVATIONS RESOURCE PROTECTION WELL - 299-E27-19

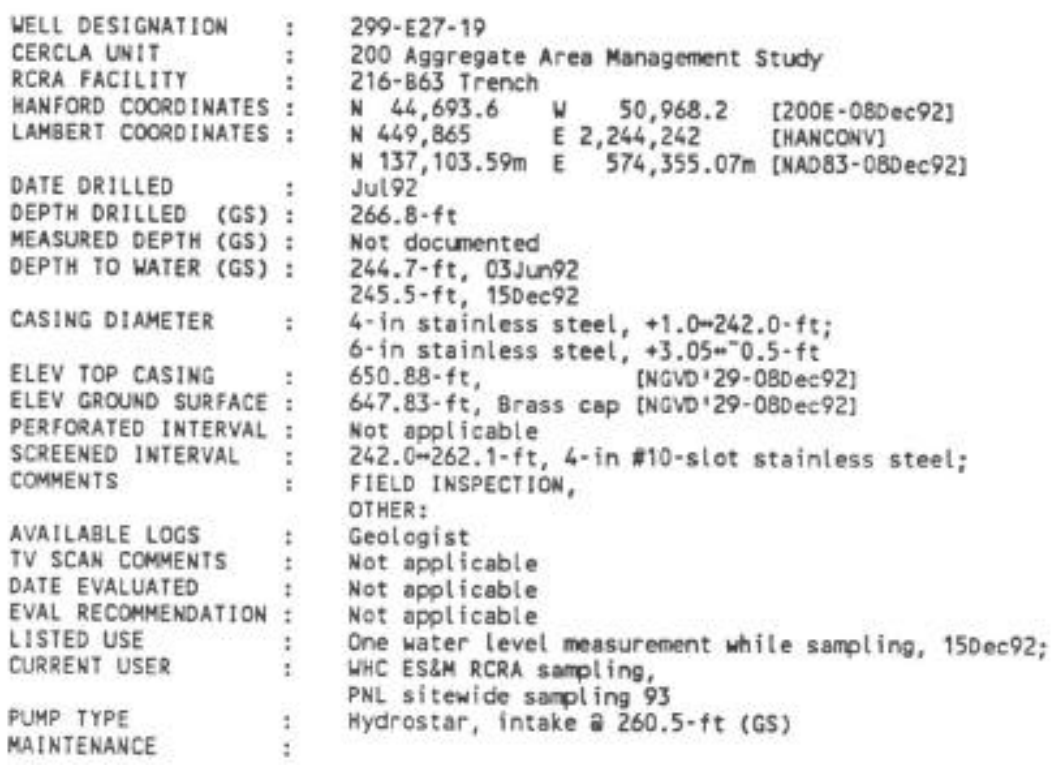




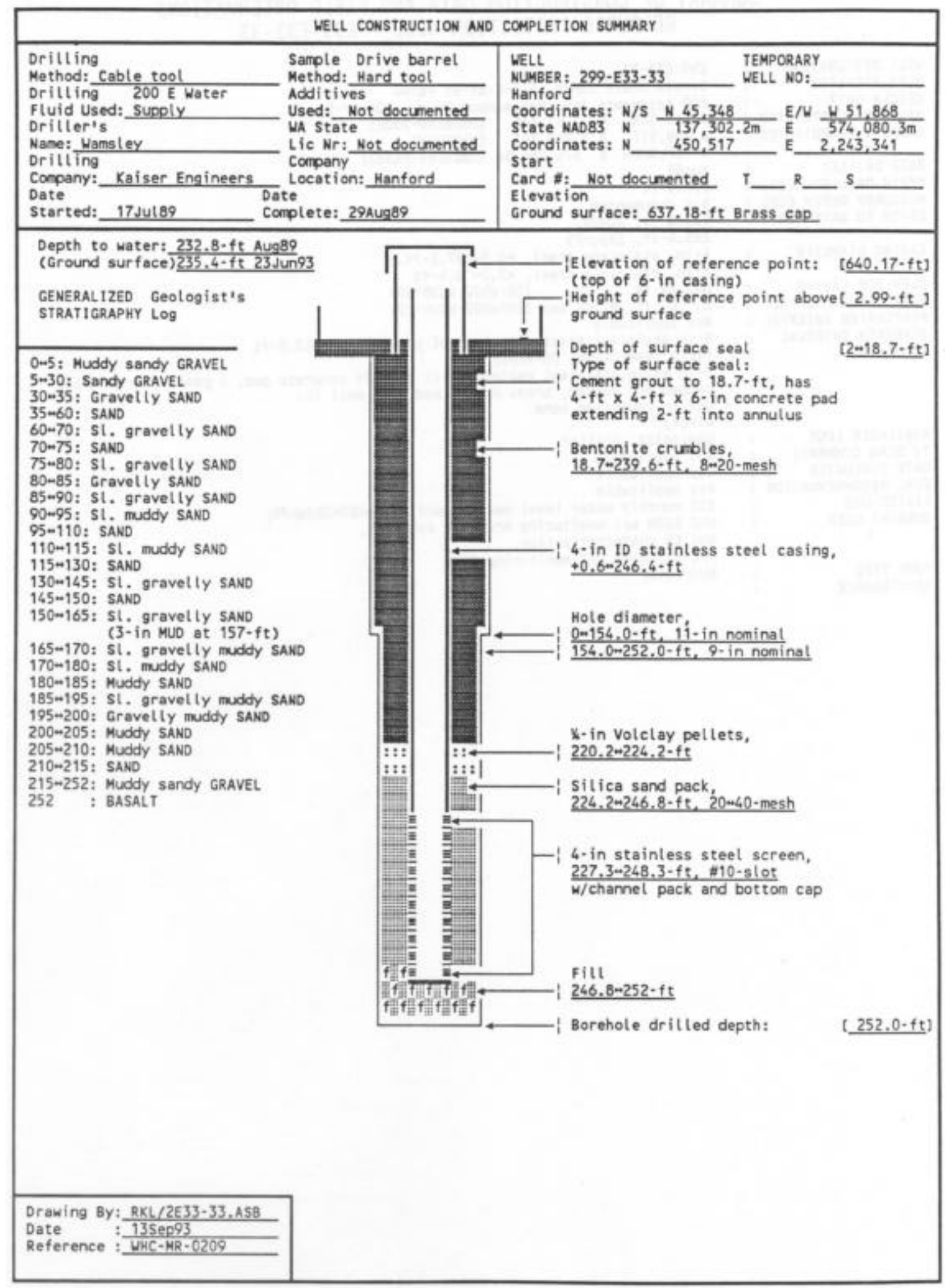


SUMMARY OF CONSTRUCTION DATA AND FIELD OBSERVATIONS RESOURCE PROTECTION WELL - 299-E33-33

WELL DESIGNATIOA :
RCRA FACILITY
CERCLA UNIT
HANFORD COORDINATES :
LAMGERT COORDINATES :
DATE ORILLED
OEPTH DRILLED (GS) :
MEASURED DEPTH (GS) :
DEPTH TO WATER (GS) :
CASING DIAMETER :
ELEV TOP CASING :
ELEV GROUMD SURFACE :
PERFORATED INTERVAL :
SCREENED INTERVAL :
COMNENTS

AVAILABLE LOGS
TV SCAM COMMENTS
DATE EVALUATED
EVAL RECONMENDATION
LISTED USE
CURRENT USER
PUMP TYPE
MAINTENANCE

$299-E 33-33$

Single Shell Tanks, 241-8-BX-BY Farms

200 Aggregate Area Management Study (200-BP-5)

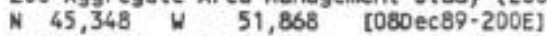

N 450,517 E $2,263,341$ [HANCONV]

N $137,302 \mathrm{~m}$ E $574,080.3 \mathrm{~m}$ [O800C89-NADB3]

Aug 89

$252.0-\mathrm{ft}$

Not documented

232.8-ft, AugB9,

$235.6-\mathrm{ft}, 23$ Jun93

4-in, stainless steel, $\$ 0,5-227,3-\mathrm{ft}$.;

$6-$ in, stainless steel, $+3.0-0.5-\mathrm{ft}$

640.39- $\mathrm{ft}$, [26Feb92-NGVD 29]

637.40-ft, Brass cap [26Feb92-NGVD 129]

Not applicable

4-in stainless steel with channel pack, 227.3-248.3- $\mathrm{ft}$

FIELD INSPECTION, O6Feb90;

6-in stainless steel casing. $6-\mathrm{ft}$ by $4-\mathrm{ft}$ concrete pad, 4 posts, 1 removable capped and locked, brass cap in pad with well ID.

Not in radiation zone.

OTHER:

Geologist, Driller

Not applicable

Not applicable

Not applicable

SST monthly water level measurenent, 080ec89m23Jun93;

WKC ES\$M W/I monitoring and RCRA sampling,

WHC ER characterization,

PNL sitewide $w / 1$ monitoring 93

Hydrostar 


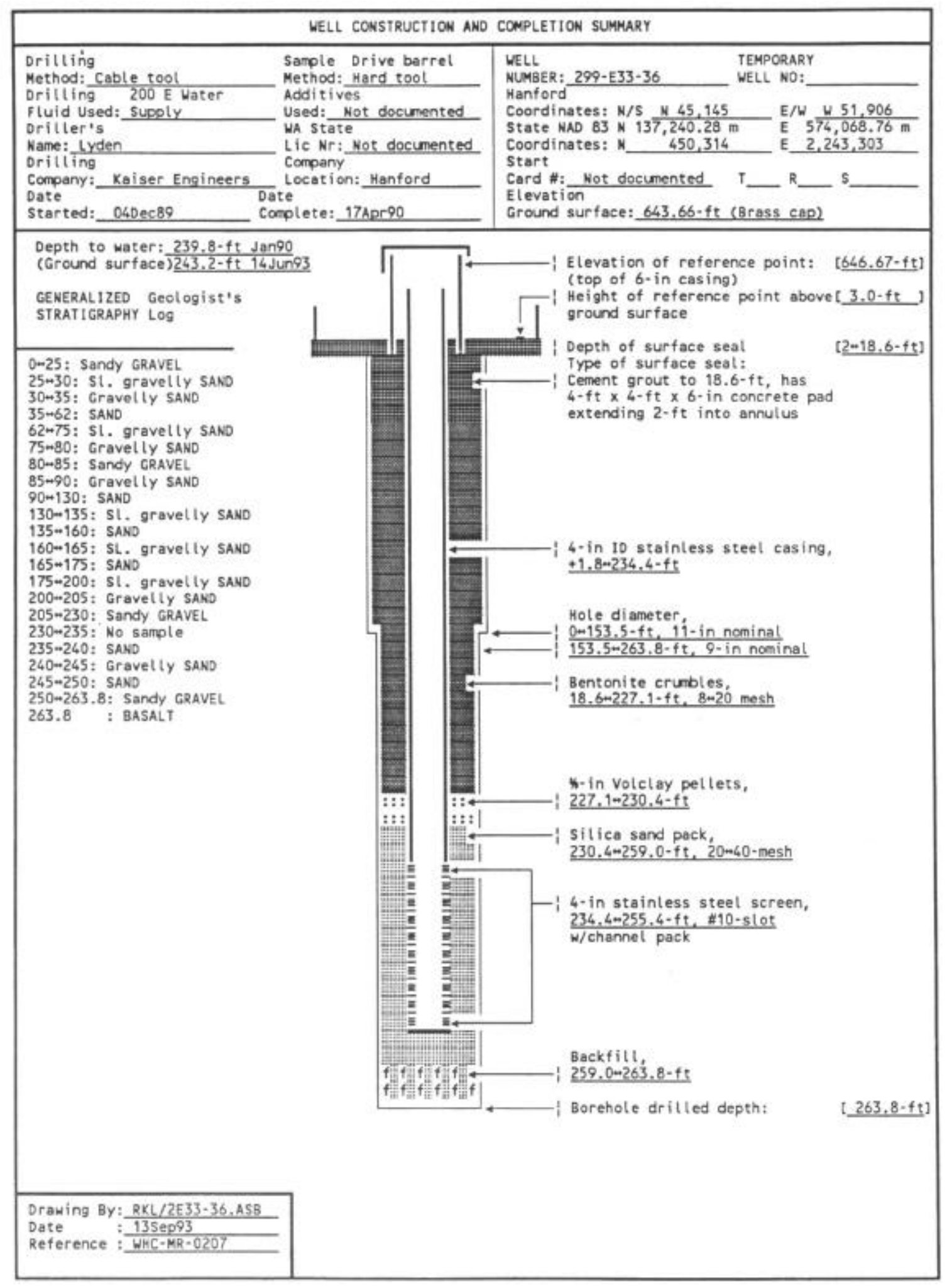


SUMMARY OF CONSTRUCTION DATA AND FIELD OBSERVATIONS RESOURCE PROTECTION WELL - 299-E33-36

WELL DESIGNATION
RCRA FACILITY
CERCLA UNIT
HAMFORD COORDINATES
LAMBERT COORDINATES :
DATE DRILLED
DEPTH DRILLED (GS)
MEASURED DEPTH (CS)
DEPTH TO WATER (GS) :
CASIMG DIAMETER
ELEV TOP CASING
ELEV GROUND SURFACE :
PERFORATED INTERVAL :
SCREENED INTERVAL
COHMENTS

299-E33-36

216-B-63 Trench

200 Aggregate Area Management Study (200-8p-5)

N 45,145 H 51,906 [19Apr90-200E]

N $450,314 \quad E 2,243,303$ [KANCONV]

N $137,240.28 \mathrm{~m}$ E $574,068.76 \mathrm{~m}$ [19APr90-MAD83]

Apr 90

264.0- $\mathrm{ft}$

Not documented

239.8- ft, Dec89,

243.2-ft, 14 Junǵ

4 -in, stainless steel, $+1.80-234.4-\mathrm{ft}$.

$6-$ in, stainless steel, $+3.0 \mathrm{~m}=0.5-\mathrm{ft}$

$646.67-\mathrm{ft}$ [19Apr90-200E]

$643.66-\mathrm{ft}$, Brass cap [19Apr90-200E]

Not applicable

$234.4+255.4-\mathrm{ft}, 4-\mathrm{in}$ stainless steel with channel pack

FIELD INSPECTION, 10AUg93;

4 and 6 -in stainless steel casing.

$4-\mathrm{ft}$ by $4-\mathrm{ft}$ concrete pad, 4 posts, 1 removable.

Capped and locked, brass cap in pad with well 10.

Not in radiation zone.

OTHER;

AVAILABLE LOGS : Geologist, Driller

TV SCAY COMMENTS : Not appl icable

DATE EVALUATED : Not appl icable

EVAL RECOHNENDATION : Not appl icable

LISTED USE

Not applicable
8-63 Trench quarterly water level measurement, 01Jan91 14.Jun 93 ;

WHC ES\&M W/I monitoring and RCRA sampling,

PNL sitewide sampling 93

PUMP TYPE

Hydrostar

A.18 


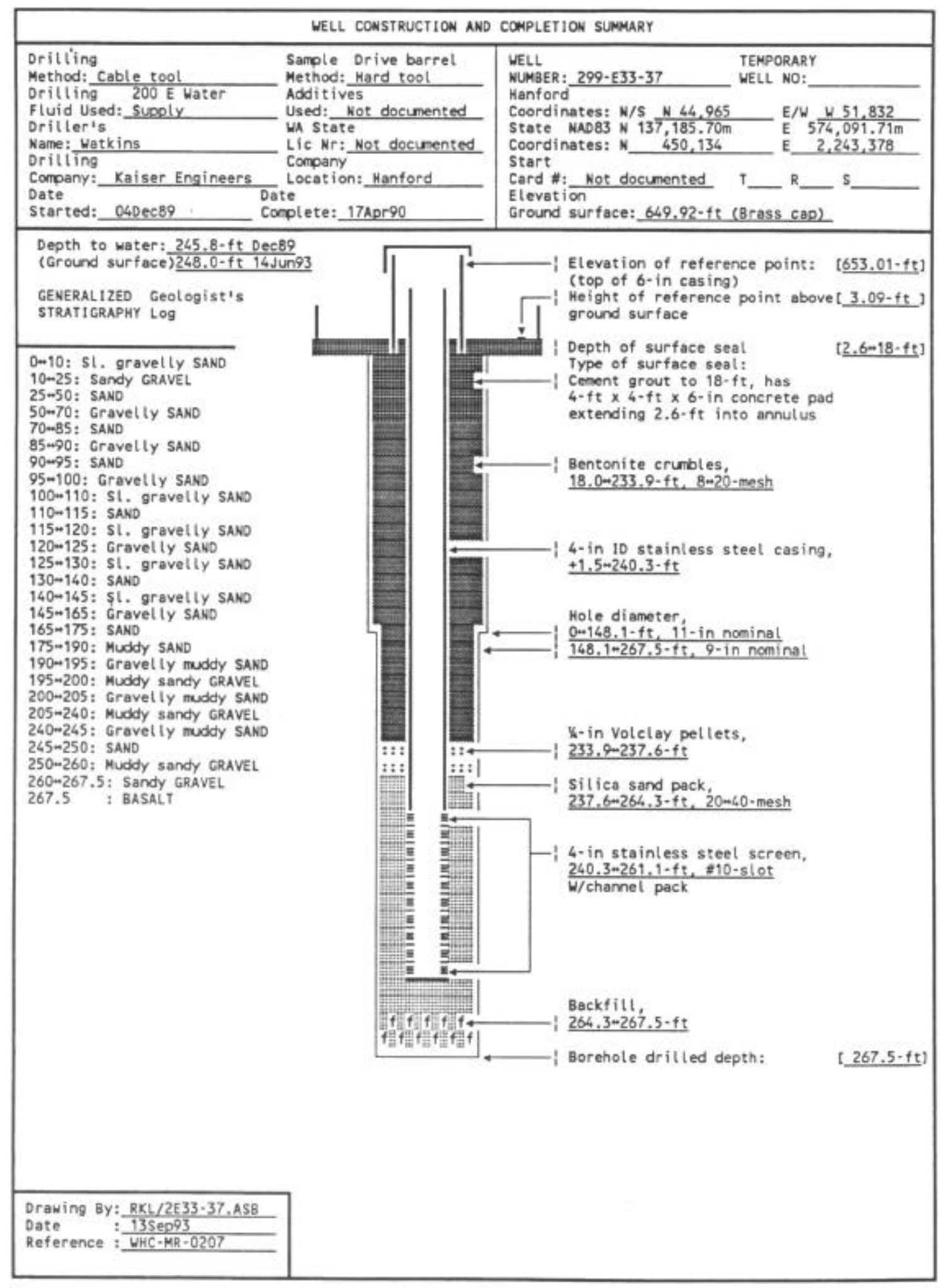




\section{SUMMARY OF CONSTRUCTION DATA AND FIELD OBSERVATIONS}

RESOURCE PROTECTION WELL - 299-E33-37

\begin{tabular}{|c|c|c|}
\hline WELL DESIGNATION & : & $299 \cdot E 33-37$ \\
\hline RCRA FACILITY & : & 216-8-63 Trench \\
\hline CERCLA UNIT & : & 200 Aggregate Area Management Study (200-BP-5) \\
\hline HANFORD COORDIKATES & $:$ & N 44,965 H 51,832 [19APR $90-200 E]$ \\
\hline LAMBERT COORDIKATES & : & $\begin{array}{llll}\text { N } 450,134 & \text { E } 2,2243,378 & \text { [HANCONV] } \\
\text { N } 137,185.70 \mathrm{~m} & \text { E } & 574,091.71 \mathrm{~m} \text { [19APr90-MAD83] }\end{array}$ \\
\hline OATE DRILLED & : & Apr $90^{\circ}$ \\
\hline DEPTH DRILLED (GS) & : & $267.5-f t$ \\
\hline MEASURED DEPTH (GS) & : & Hot documented \\
\hline DEPTH TO WATER (GS) & : & $\begin{array}{l}245.8-\mathrm{ft}, \text { Dec89, } \\
248.0-\mathrm{ft}, 14 \text { Jungs }\end{array}$ \\
\hline CASIMG DIAMETER & : & $\begin{array}{l}4-i n, \text { staintess steel, }+1.5-260.3-\mathrm{ft} \text {. } \\
6-i n, \text { stainless steel, }+3.09-0.5-\mathrm{ft}\end{array}$ \\
\hline ELEV TOP CASING & : & $653.01-\mathrm{ft} \quad[19 \mathrm{Apr} 90-200 \mathrm{E}]$ \\
\hline $\begin{array}{l}\text { ELEV GROUND SURFACE } \\
\text { PERFORATED INTERVAL }\end{array}$ & : & $\begin{array}{l}649.92-\mathrm{ft} \text {, Brass cep [19Apr90-200E] } \\
\text { Not applicable }\end{array}$ \\
\hline SCREENED INTERVAL & : & $240.3+261.1-\mathrm{ft}, 4-$ in stainless steet with chamel pack, \\
\hline COMMENTS & : & $\begin{array}{l}\text { FIELD INSPECTION, 10Aug93; } \\
4 \text { and } 6-\text { in stainless steel casing. } \\
4-\mathrm{ft} \text { by } 4-\mathrm{ft} \text { concrete pad, } 4 \text { posts, } 1 \text { removable. } \\
\text { Capped and locked, brass cap in pad with well ID. } \\
\text { Not in radiation zone. } \\
\text { OTHER; }\end{array}$ \\
\hline AVAILABLE LOGS & : & Geologist, Driller \\
\hline TV SCAN COMMENTS & : & Not applicable \\
\hline DATE EVALUATED & : & Not applifeable \\
\hline EVAL RECOHMENDATION & : & Not applicable \\
\hline LISTED USE & : & B-63 Trench water level measurement, 20Nov90+14 Jun93; \\
\hline CURRENT USER & $:$ & $\begin{array}{l}\text { WHC ESSM w/l monitoring and RCRA sampling, } \\
\text { PNL sitewide sampling } 93\end{array}$ \\
\hline PUMP TYPE & : & Hydrostar \\
\hline MAINTENAKCE & : & \\
\hline
\end{tabular}




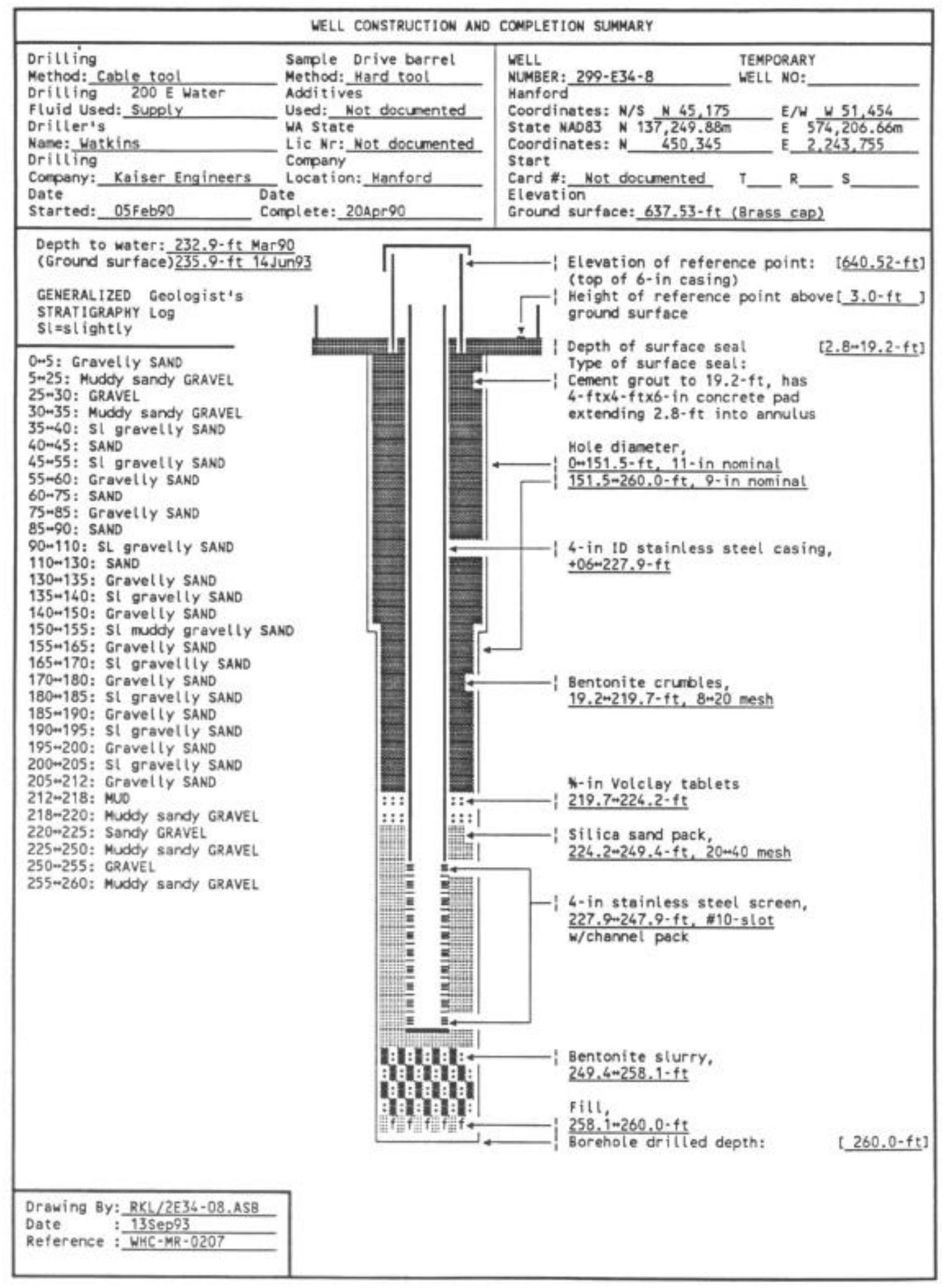


SUMMARY OF CONSTRUCTION DATA AND FIELD OBSERVATIONS RESOURCE PROTECTION WELL - 299-E34-8

WELL DESIGNATION
RCRA FACILITY
CERCLA UNIT
HANFORD COORDIMATES
LAMBERT COORDIMATES :
DATE DRILLED
DEPTH DRILLED (GS)
MEASURED DEPTH (GS)
DEPTH TO WATER (GS)
CASING DIAMETER
ELEV TOP CASIMG
ELEV GROUND SURFACE :
PERFORATED INTERVAL
SCREENED INTERVAL
COMMENTS
AVAILABLE LOGS
TV SCAN CONMENTS
DATE EVALUATED
EVAL RECOMMENDATION
LISTED USE
CURRENT USER
PUMP TYPE
MAINTENANCE

299-E34-8 216-B-63 Trench

200 Aggregate Area Manogement Study (200-BP-5)

N 45,175
[19Apr90-200E]

N 450,345 E 2, 243, 755 [HANCONV]

N $137,249.88 \mathrm{~m}$ E $574,206.66 \mathrm{~m}$ [19Apr90-NAD83]

Apr 90

260.0-ft

Not documented

232.9- $\mathrm{ft}$, Mar90,

235.9- $\mathrm{ft}, 14 \mathrm{Jun} 93$

4-in, stainless steel, $+0.6+227.9-\mathrm{ft}$.

$6-$ in, stainless steel, $+3.0=-0.5 \cdot \mathrm{ft}$

$640.52-\mathrm{ft}$ [19APr90-200E]

$637.53-\mathrm{ft}$, Brass cap [19Apr $90-200 \mathrm{E}]$

Not applicable

4-in stainless steel with channel pack, 227.9m247.9-ft

FIELD INSPECTION,

OTHER:

Geologist, Dritler

Not applicable

Not appl icable

Not applicable

B-63 Trench quarterly water level measurement, 20Nov90-14.Jun93;

WHC ESBH w/L monitoring and RCRA sampling,

PNL sitewide sampling 93

Hydrostar 


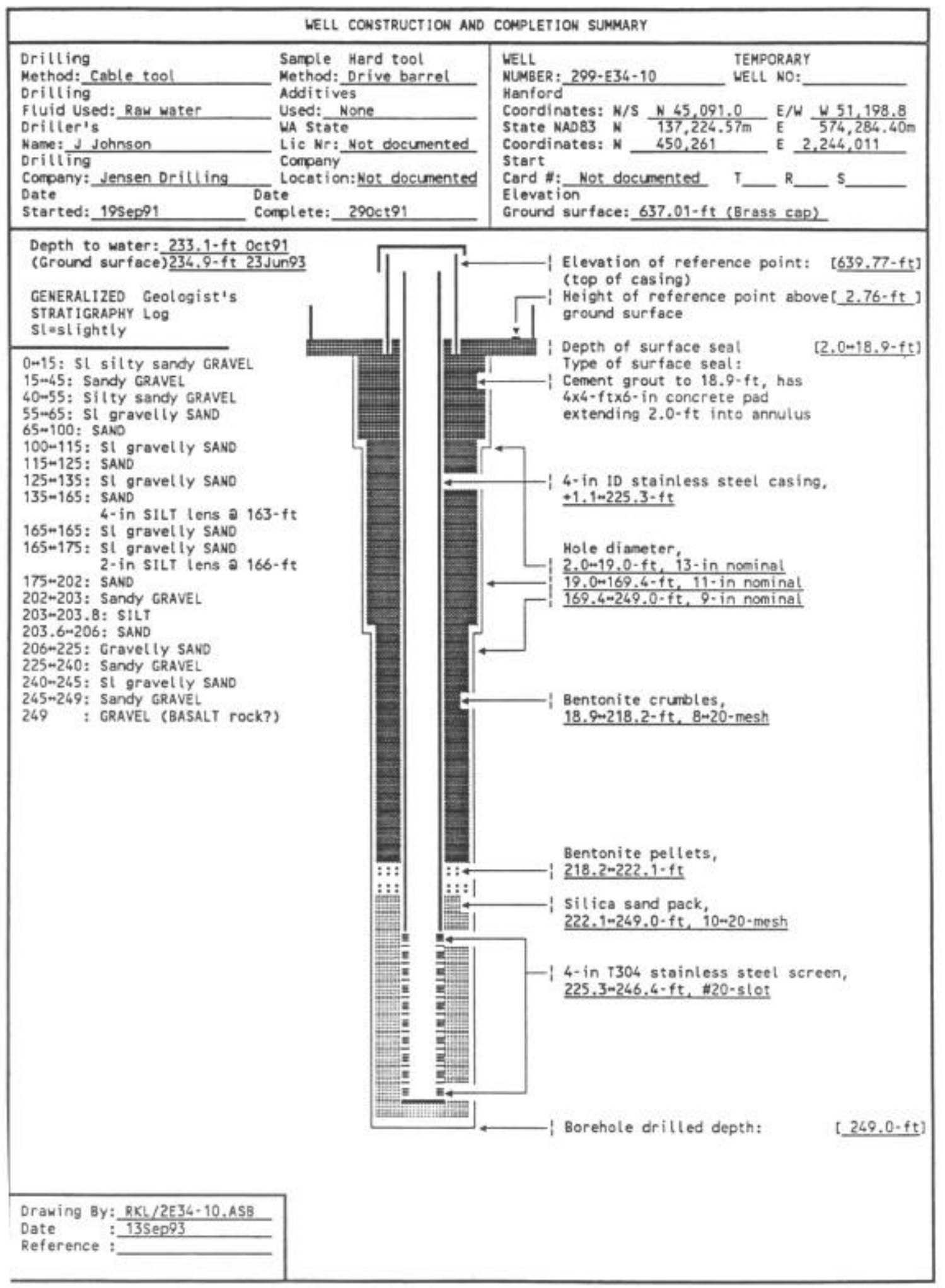


SMMARY OF CONSTRUCTION DATA AND FIELD OBSERVATIONS

RESOURCE PROTECTION WELL - 299-E34-10

\begin{tabular}{|c|c|c|}
\hline WELL DESIGNATION & : & $299-E 36-10$ \\
\hline CERCLA UKIT & : & 200 Aggregate Area Management study \\
\hline RCRA FACILITY & : & LLBG/WMA-2 \\
\hline HAMFORD COORDIMATES & : & {$[200 E-120$ ec 91$]$} \\
\hline LAMBERT COORDIMATES & ; & $\begin{array}{ll}2,244,011 & \text { [HANCONV] } \\
E & 576,284,40 m\end{array}$ \\
\hline DATE DRILLED & : & Oct91 \\
\hline DEPTH DRILLED (GS) & : & $249.0-\mathrm{ft}$ \\
\hline NEASURED DEPTH (GS) & : & $247.0-\mathrm{ft}, 27 \mathrm{Aug} 93$ \\
\hline DEPTH TO WATER (GS) & : & $\begin{array}{l}233.1-\mathrm{ft}, 290 \mathrm{ct} 91 \\
234.9-\mathrm{ft}, 23 \text { Jun93 }\end{array}$ \\
\hline CASING DIAMETER. & : & $\begin{array}{l}4-\text { in stainless steel, }+1.1-225.3-\mathrm{ft} \text {; } \\
6-\text { in stainless steel, }+2.76 \mathrm{e}^{-} 0.5 \cdot \mathrm{ft}\end{array}$ \\
\hline ELEV TOP CASING & : & 639.77-ft, [NGVD'29-12Dec91] \\
\hline ELEV GROUNO SURFACE & ; & 637.01-ft, Brass cap [MGVD'29-120ec91] \\
\hline PERFORATED INTERVAL & : & Hot applícable \\
\hline SCREENED INTERVAL & : & $225.3 \times 246.4-\mathrm{ft}, 4-$ in $200-$ slot stainless steel; \\
\hline COMMENTS & : & $\begin{array}{l}\text { FIELD INSPECTIOM, } 27 \text { Aug93; } \\
4 \text { and } 6-\text { in stainless steel casing. } \\
4-\mathrm{ft} \text { by } 4-\mathrm{ft} \text { concrete pad, } 4 \text { posts, } 1 \text { removable. } \\
\text { Capped and locked, brass cap in pad with well ID. } \\
\text { Not in radiation zone. } \\
\text { OTHER: }\end{array}$ \\
\hline AVAILABLE LOGS & : & Geologist \\
\hline TV SCAN COMMENTS & : & Hot applicable \\
\hline DATE EVALUATED & : & Not appl icable \\
\hline EVAL RECOMMENDATION & : & Not applicable \\
\hline LISTED USE & : & LLBG quarterly water level measurement, 17 Mar-92-23 Jun93, \\
\hline CURRENT USER & : & WHC ESBY W/L monitoring and RCRA sampling, \\
\hline PUMP TYPE & : & Hydrostar, intake a $239.0-\mathrm{ft}$ \\
\hline MAINTENANCE & & \\
\hline
\end{tabular}




\section{Distribution}

No. of

Copies

\section{ONSITE}

6 DOE Richland Operations Office

M. J. Furman (2)

Administrative Record (2)

Public Reading Room (2)

A6-38

H6-08

$\mathrm{H} 2-53$

2 Fluor Hanford Inc.
No. of

Copies

9 Pacific Northwest National Laboratory

M. J. Hartman

K6-96

S. P. Luttrell

K6-96

W. J. Martin

K6-81

M. D. Sweeney (3)

K6-81

D. Vela

K6-96

Hanford Technical Library (2)
E6-35

3 Washington State Department of Ecology

D. Goswami

B5-18

J. A. Hedges

B5-18

A. D. Huckaby

B5-18

Distr.1 